\title{
THE WAR BETWEEN PERIOD AND EXCLAMATION MARK: NEW REALITY AND NAGORNO-KARABAKH: THE CEMRE THAT FELL TO NAGORNO-KARABAKH
}

\author{
Vefa KURBAN* - Oğuzhan ERGÜN"**
}

\begin{abstract}
Having always been competition fields thanks to their geopolitical impact potential, the Caucasus and Turkestan have been among the Strategic Focus Centres of Russia since the Tsarist times. While Russia, whose strategic culture has produced expansionist policies for centuries, constantly expanded its political borders, it clashed with the Ottoman Empire and Iran in the Caucasus field of competition. From the second half of the 19th century, the Kazakh regions and independent Turkic states (Khiva, Kokand and Bukhara) were occupied by the Tsarist Russia. The Imperial Age was also a period in which Russia expanded its sphere of influence over the Ottoman Empire through its patronage policies. Having embraced "New Reality" in the regional power projection in the near past, Turkey stayed away from the region for a long time. In addition to some ethnic and cultural problems paused by the Cold War, problems in the partition of the territory came to light again following the end of the Cold War and the dissolution of the Soviet Union, the Caucasus geography, from south to north, went back into the period when various national issues were at the forefront and conflicts were experienced. The occupation Armenia carried out with the sponsorship and de facto military support of Russia violated the sovereignty rights of Azerbaijan, caused great social and economic harm, deteriorated the geopolitical impact potential of Azerbaijan and Turkey, and annihilated the possibility of direct connection between Turkey and Turkestan. With Vladimir Putin taking the lead of the Russian Federation, Russia aimed at maintaining regional control and, beyond that, imperial domination, as it had also aimed in the times of the Tsarist Russia and the Soviet Union. The appointment of Sergey Lavrov, who is of Armenian origin, to the post of Foreign Minister further increased the tension in the South Caucasus region. Eventually, the process that started with Pashinyan's statement "Artsakh is Armenia, period" during his visit to Khankendi, and Ilham Aliyev's response "Karabakh is Azerbaijan, and exclamation mark!" resulted in absolute defeat of Armenia and pushed it to the position of a desperate province of Russia. However, there is no place for zero-sum games in real life.
\end{abstract}

* Assoc. Prof., Ege University, Institute of Turkish World Studies, İzmir.

E-mail; vefa rzayeva@yahoo.com. ORCID: 0000-0002-8178-1544

** Dr., E-mail: oguzhanergun@gmail.com. ORCID: 0000-0002-6917-0871

(Makale Gönderim Tarihi: 02.02.2021 - Makale Kabul Tarihi: 02.03.2021) 


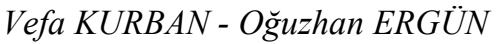

In this study, the cemre ${ }^{1}$ that fell to the Trans-Caucasus on September 27, 2020 with the first martyr, and new realities are discussed. Following the triumph, how are the balances going to be formed? Or if they are not formed, is a period of conflict going to begin for third countries? What sort of climate change is Aliyev's New Reality going to involve in military, political, economic and cultural terms? The article tries to explain the answer to this question by questioning the historical background and strategic culture.

Keywords: Geopolitics of Trans-Caucasus, Russian Strategic Culture, MINSK Triad OSCE and Nagorno-Karabakh conflict, Armenia Azerbaijan War, Russia and Balances of Power

\section{$\ddot{\mathbf{O z}}$}

\section{Nokta ve Ünlem Savaşı: Yeni Gerçeklik ve Karabağ: Karabağ’a Düşen Cemre}

Jeopolitik etki potansiyeli ile her zaman rekabet alanı olan Kafkasya ve Türkistan, Çarlık dönemlerinden itibaren Rusya'nın Stratejik Ağırlık Merkezlerinden birini oluşturmuştur. Stratejik kültürü yüzyıllar boyunca yayılmacı politikalar üreten Rusya, siyasi sınırlarını sürekli genişletirken, Kafkasya rekabet alanında Osmanlı Devleti ve İran ile çatışmıştır. 19. Yüzyılın ikinci yarısından itibaren Kazak bölgeleri ve bağımsız Türk devletleri (Hive, Hokand ve Buhara) Çarlık Rusyası tarafından işgal edilmiştir. Emperyal Çağ aynı zamanda Rusya'nın Osmanlı Devleti üzerinde himaye politikaları ile etki alanını genişlettiği bir dönemdir. Yakın dönemde ise bölgesel güç projeksiyonunda "Yeni Gerçekliği”" kabul eden Türkiye uzun süre bölgeden uzak durmuştur.

Soğuk Savaş'ın dondurduğu bir kısım etnik ve kültürel sorunların yanı sıra mekânın bölüşüm sorunları, Soğuk Savaş'ın bitimi ve Sovyetler Birliği'nin dağılması ile gün ışığına çıkarak ısınmış ve 1sıtılmış, Kafkasya coğrafyası, güneyi ve kuzeyi ile çeşitli milli meselelerin ön planda olduğu ve çatışmaların yaşandığ1 döneme geri dönmüştür. Ermenistan'ın, Rusya'nın sponsorluğu ve fiili askeri desteği ile gerçekleştirdiği işgal eylemleri Azerbaycan'ın egemenlik haklarını çiğneyerek, çok büyük sosyal ve ekonomik zararların yanı sıra, Azerbaycan ve Türkiye'nin jeopolitik etki potansiyelini zayıflatmış, Türkiye ve Türkistan arasındaki doğrudan bağlantı olanaklarını ortadan kaldırmıştır. Vladimir Putin'in Rusya Federasyonu'nun başına geçmesi ile Rusya, Çarlık Rusya'sı ve Sovyetler Birliği dönemlerinde de olduğu gibi bölge kontrolünü ve ötesinde emperyal hakimiyeti hedeflemiştir. Dışişleri Bakanlığı görevine Ermeni kökenli Sergey Lavrov'un getirilmesi ise Güney Kafkasya bölgesindeki hareketliliği daha da arttırmıştır. Son tahlilde Paşinyan'ın Hankendi'ni ziyareti sırasındaki "Karabağ Ermenistan'dır ve Nokta" ifadesi, İlham Aliyev'in "Karabağ Azerbaycan'dır ve ünlem!” karşılığı ile başlayan süreç Ermenistan'1 mutlak mağlubiyete ve Rusya'nın çaresiz bir vilayeti konumuna itmiştir. Ancak gerçek hayatta sıfır toplamlı oyunlara rastlanmamaktadır. Bu çalışmada Trans-Kafkasya'ya 27 Eylül 2020'de ilk şehit ile düşen cemre ve yeni gerçeklikler tartışılmaktadır. Zafer sonrasında dengeler nasıl oluşacak veya oluşmayarak üçüncü ülkeler açısından çatışmalı bir döneme mi girilecektir? Aliyev'in Yeni Gerçekliği askeri, siyasi, ekonomik ve kültürel açıdan ne tür bir iklim değişikliği içerecektir? Makale bu sorunun cevabını tarihi geçmişi ve stratejik kültürü sorgulayarak açıklama gayreti göstermektedir.

Anahtar Kelimeler: Trans-Kafkasya Jeopolitĭgi, Rus Stratejik Kültürü, MINNSK Üçlüsü AGITT ve Karabă̆ Sorunu, Ermenistan Azerbaycan Savaşı, Rusya ve Güç Dengeleri, Iran ve Karabağ Sorunu, Molla Rejimi ve Etnik Gerçeklikler

${ }^{1}$ Cemre: "Cemre literally means fire, embers. The expression of "falling" is actually a concept that describes warming. Cemre fall means the awakening and revival of nature in the folk culture. This situation is considered as the beginning of spring.https://haber.sakarya.edu.tr/ilk-cemredustu-peki-cemre-dusmesi-ne-demek-h96191.html Retrieved on December 10, 2020 


\section{Introduction: Power and Balance}

Unless continental countries take root as deep and wide as possible in the area where they are located, just like a pine sapling, they cannot get rid of the security dilemma and grow. Imperialist expansionism and appetite for security demonstrate symbiotic unity, last until they reach the limits or sphere of influence of a power that will balance them, or obesity of power consumes the body. Kissinger attributes the vitality of the international order to the balance it creates between legitimacy (order of principles) and the balance of power, and the relative importance attached to each. According to him, the only times in the history of the world in which there has been a long period of peace are those when there has been a balance of power. ${ }^{2}$ The main reason for the conflicts is that the balance between power and legitimacy is disturbed in favor of power, and there is no fair political arbitration and sanctioning power. Failure to establish or disturbance of the order of principles could drag political actions and conflicts to a point similar to the geopolitics of World War II. This could be degraded to a point of "an unstoppable and internal process of nature" 3 and ideologically legitimized. This situation would trigger the spread of Hobbesian (aggressive) anarchy culture ${ }^{4}$. In Eastern Europe, the Middle East and the Caucasus, such developments have been observed for a long time.

Kissinger suggests that the balance of power can be upset in at least two ways. A leading country can increase its power to such an extent that it threatens to attain hegemony, and a state that has remained in a subordinate position tends to align itself with one of the great states ${ }^{5}$. (For instance, the US influence and the Turkish-Russian rapprochement that started with the change of government in Armenia). For the establishment of balance, the power of the subordinate partners also plays a significant role in determining partnership policies. That subordinate parties change their preferences of alliance or show deviation from them by seeking to generate influence and benefit beyond their power affects regional balances and leads major players to take a stance which is punitive and establishes new balances. In the context of Armenia, the surprising effect that the Azerbaijani Army produced, the free movement of Azerbaijan in terms of military until a certain stage, and the fact that Armenia did not receive sufficient concrete support from its supporters and agitators suggest that it went through the penalization process within the framework mentioned above. After Nikol Pashinyan came to power in the South Caucasus, he changed the country' preferences of alliance, and his policies took a more aggressive character, which affected the areas of interest. As a result, regional balances and expectations were disturbed particularly for Russia, Turkey, Georgia and Azerbaijan. Those who encouraged Pashinyan to carry out unplanned attacks might not have foreseen the success of the Azerbaijani Army.

For Iran, a potential change in the physical contact line with Russia would be a serious survival problem for the Mullah regime. The fact that Russian soldiers settled in

\footnotetext{
${ }^{2}$ Kissinger 2016, s.19; 79

${ }^{3}$ Kissinger 2016, s.26

${ }^{4}$ Ergün ve Kurban 2020 s. 19-20

${ }^{5}$ Kissinger 2016, s. 44
} 
the region seems to have relieved Iran ${ }^{6}$. This situation inflicted a heavy blow to the influence of France and the USA in the region, narrowing their sphere of influence. The support of the Mullah regime towards Armenia, which is also objected by the Shiite circles $^{7}$, became the harbinger of the ethnic tensions desired by Israel and the USA, who had been aiming for a political resolution in $\operatorname{Iran}^{8}$.

Although Brzezinski stated, "Azerbaijan is the cork in the bottle opening to the Caspian. It constitutes a significant place in the security strategies of the USA due to its energy resources and as a country that guarantees the independence of the Central Asian countries", there has been no obvious support by the USA within the Minsk Group. Turkey's support to Azerbaijan has settled at a very different context and level compared to the past. It has been observed that with the success of the Azerbaijan Army and its administration and the level of power it has obtained, Azerbaijan has created a military and political impact more than that of both countries combined. It could be understood from the attitudes of Iran that the spread of this cooperation to the cultural basin might drag the countries of the region into a Security Dilemma. Due to the independent foreign policies it has been pursuing, Turkey has been exposed to tough intra-alliance policies. It is going through a troubled period economically and financially. In this study, whether "Cemre" will overcome the coldness that has come before it or it will warm up the political climate even more is analysed within the historical and strategic framework.

Figure 1: Pivot Area and Heartland

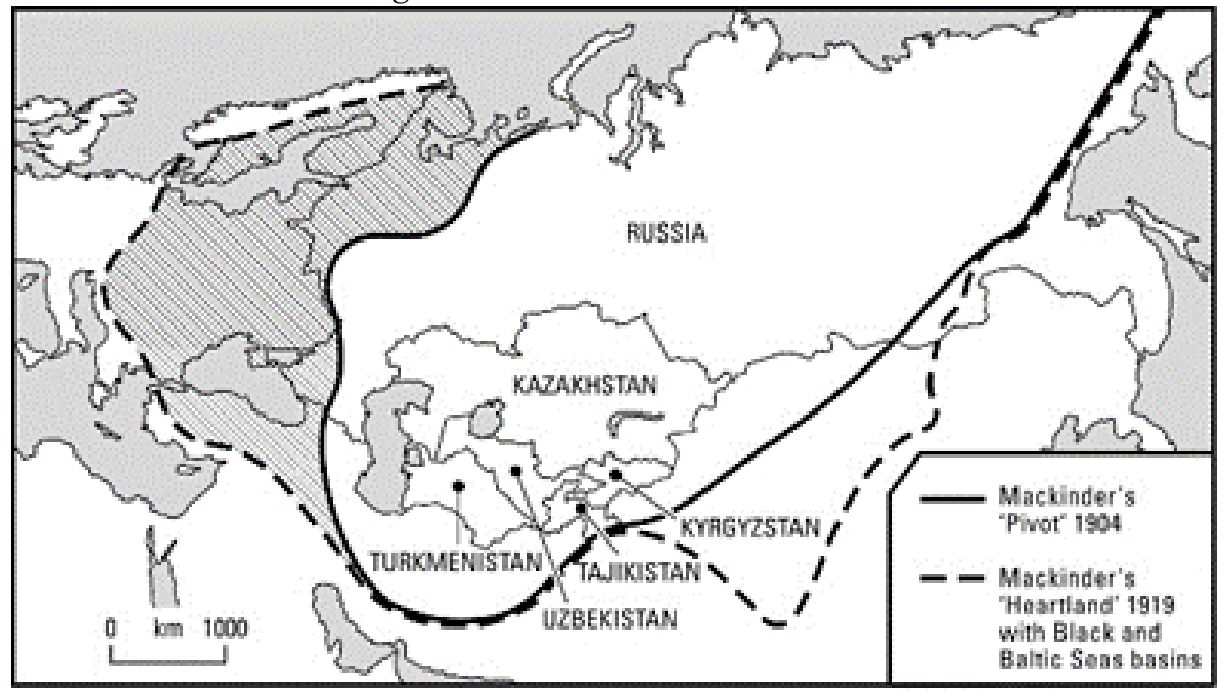

\footnotetext{
${ }^{6}$ Hürriyet 2020

7 Geldi 2020

8 Avsat ve Ahmet 2020

${ }^{9}$ Yildırım 2018, s. 28-32
} 


\section{An Elective Perspective on Turkestan Geopolitics}

The Central Asian part of the region called the "Heartland" of the world is a continental area far from oceans and seas. Tashkent is located $5421 \mathrm{~km}$ away from the port of Shanghai in the Pacific Ocean, $2.770 \mathrm{~km}$ from the coastal city of Bender Abbas in the Persian Gulf in the Indian Ocean, $5.500 \mathrm{~km}$ from Riga in the Baltic Sea and $3950 \mathrm{~km}$ from the Port of Novorossiysk in the Black Sea. The Central Asia is a difficult geography to control and manage because of its population and wide surface area.

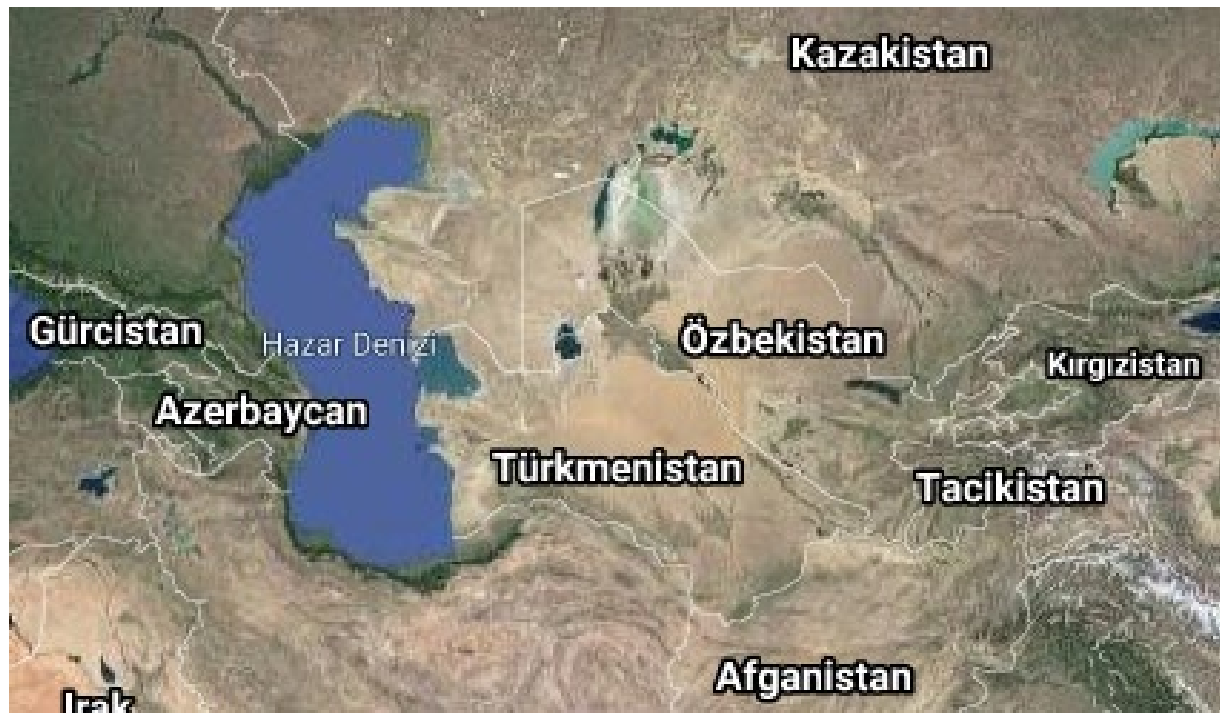

The continental countries are located on trade routes, but these trade corridors create dependence on neighbours in this wide and harsh geography. This brings along conflicts. For example, Kazakhstan is dependent on the Chinese and Russian corridors, which have coasts on big oceans. It is also dependent on Turkmenistan and Iran. These two countries are the ones that depend on the least number of neighbours in Central Asia to connect themselves to the world economy and even have maritime borders along the Caspian Sea. They provide direct access to the Caucasus. The isolated location of Uzbekistan force it to be dependent on at least two countries, namely Tajikistan and Kyrgyzstan. The maritime access of these two countries depends on other countries. And, Azerbaijan is surrounded by Georgia, Armenia and Iran. The same congestion is also experienced in communication and transportation. Built during the Soviet period, the existing road and railroad network stretches between north and south and joins the "Siberian corridor" between Moscow and European Russia. This structure still continues to determine the mode of transportation of goods in the Central Asia today. 


\section{Vefa KURBAN - Oğuzhan ERGÜN}

In the context of energy geopolitics, the oil and natural gas production amounts of countries is as follows (2018):

\begin{tabular}{|l|l|l|l|}
\hline & Total Energy & Natural gas & Oil \\
\hline ktoe & ktoe & ktoe \\
\hline Total Eurasia & 939509 & 506765 & 187387 \\
\hline Russian Federation & 759327 & 413707 & 148281 \\
\hline Kazakhstan & 75758 & 18619 & 18880 \\
\hline Uzbekistan & 46393 & 39374 & 4100 \\
\hline Turkmenistan & 27646 & 21350 & 6561 \\
\hline Azerbaijan & 14378 & 9300 & 4918 \\
\hline Georgia & 4855 & 2045 & 1274 \\
\hline Kyrgyzstan & 4556 & 279 & 2070 \\
\hline Tajikistan & 3513 & 47 & 984 \\
\hline
\end{tabular}

Source International Energy Agency, Eurasia - Countries \& Regions - IEA

The transformation of local (intra-state), regional and global conditions, which constitute the three-layered study area of Political Geography, into structural changes leads to the reconsideration of security and interest balances. Being among the determinant factors of the power balance; material forces, especially military force, are under geocultural pressure and threat. The political unity, which is disrupted by the centrifugal forces, cannot always hold on to the military power. Culture is regarded as a strategic "battlefield" from the Gramscian point of view ${ }^{10}$. The Central Asian geography, where more than 60 million people of different ethnic and religious backgrounds live and which is home to the tribes that have not experienced deep-rooted modern political development and unity, spreads over an area of approximately 4 million $\mathrm{km}^{2}$ where central and democratic control cannot be achieved. The idea that stability could be achieved in this geography through an authoritarian regime dates back to very old times ${ }^{11}$.

\section{Strategic Culture, Expansionism and Imperialist Competition}

Geopolitical shaping and geopolitical architecture, which lays the foundation of the former, are directly linked to the visual functional system of a state. "Seeing" the enemy and influencing their decisions are directly proportional to political and military success ${ }^{12}$. Russia was able to effectively use its ability to "see" and "influence" during the period of enlargement. Russian foreign policy strategy has been shaped in a way to "expand the state in all directions" since the Tsarist period. In fact, it has grown more than many European states combined each year between 1552-1917, expanding an average of $100.000 \mathrm{~km}^{2}$ per year ${ }^{13}$. Kissinger's discourse holds that "The USSR has not been a

\footnotetext{
${ }^{10}$ Barbero 1993, s. 73-74

11 "The size of the administration requires that the person who rules it be given absolute Power"

Tsaritsa Katerina, as cited by Kissinger 2016, s. 68

${ }^{12}$ Ergün ve Kurban 2020, s.32

${ }^{13}$ Kissinger 2016, s.65
} 
reliable actor like the Tsarist Russia throughout its history. It is not correct to approach the geopolitics of the Caucasus independently from Iran and Turkestan (Iran and Turan) regions in terms of the geostrategic orientations of the Russian States. The economic, political and strategic development and future of the state depend on these regions. Russia's tendency to direct its power politics, attention and energy to the Turkic lands and the Eastern front relieves European countries.

Starting from Ivan IV, almost all Russian tsars forced the gates of Central Asia and attempted to establish dominance over the Caucasus; as a matter of fact, the idea of "Caucasian domination" became hereditary in the Russian history ${ }^{14}$. While talking about the significance of the Caucasus for Russia, General Vasily Potto stated, "Caucasus! What Russian soul would be indifferent to the saying that it is not tied to this region with blood, history and mentality? ... The war for the Caucasus is over and this great goal has been achieved". ${ }^{15}$ As Potto emphasized, occupying the Kazan Khanate in 1552 and the Astrakhan Khanate in 1556, Russia extended its borders to the Caspian Sea, which the Volga and Ural rivers flow into, and took over the Caucasian domination through a systematic strategic architecture.

Following the capture of Kazan, the Russian Yermak Cossacks crossed the Urals under the command of Marshal Stoganov and captured Siberia between 1558-1582. They ended the independence of the Khanate of Sibir, which was a Turkic-Muslim state under the leadership of Kuchum Khan ${ }^{16}$. Although this rapid expansion in Asia halted partially in the 17th century, it started again in the 18th century. The Cossacks of the Little Horde and the Middle Horde accepted Russian patronage in 1732 in return for assistance in their domestic conflicts. The Russian immigrants who settled on the line that surrounded Turkestan from the north were given land ${ }^{17}$. A solid background was established against the occupations of the Kazakh regions and in the South. The inter-Khanate politics in this geography resembles, based on the ideas of Hardt and Negri, the conclusion that "The empire was not born out of its own will. On the contrary, it was established on the basis that it was desired and of its capacity to resolve conflicts" 18 . All the interventions of the imperial armies are directed towards an already existing conflict. Imperial power feeds on conflicts.

The architecture of the period was based on garrisoning and colonization, and it would not be wrong to say that this architecture continues at a certain level. Since colonialism peaked between 1870-1914, Kiernan labels this period as "age of imperialism"19. While Potto underlined that this expansion was also a great need for Russia, it evoked the concept of "Life Field". He also stated, "Who have not fought for this region: Greeks, Macedonians, Romans, Byzantines from the west, then Turks, then

\footnotetext{
${ }^{14}$ Potto 1995 s. 14

${ }^{15}$ Потто 1887, s.1-5

${ }^{16}$ Hayit 1995, s. 42

${ }^{17}$ Tikhomirov 1897, s. 16

${ }^{18}$ Hardt ve Negri s. 37

${ }^{19}$ Kiernan 2003 s. 93
} 


\title{
Vefa KURBAN - Oğuzhan ERGÜN
}

Persians, Arabs, Mongols from the east, Scythians, Alans, Goths, Khazars, Huns, Avars, Cumans, Pechenegs, Mongols, Turks from the south, and eventually Russians" 20.

In the middle of the 19th century, the Russian government established a large degree of regional control in the Caucasus. In the south of the Caucasus, it ended the military occupations, established military-administrative structures ${ }^{21}$ and established colonies. Turkestan has also entered into the Russian area of application where Russia implements tough policies towards other states through protection and suzerainty practices. Some groups that would not like to pay taxes to Khans and Beys fled and took refuge in Russia and became its citizens ${ }^{22}$, which reveals that relationship based on economic interests takes precedence over social and cultural habitat. Russia was taking them under protection. In fact, in the warning made to the Khanate of Khiva in 1841, it was stated that if the Khanate officials came to collect taxes from the Cossacks, who were under Russian protection, they would be punished with death. The discomfort felt by the Khanate of Khiva was also felt by the Khanate of Kokand for the same reasons ${ }^{23}$. In addition, the Khans who lacked diplomacy and political background took actions to block the possible aid channels of other countries. To illustrate, the Khan of Bukhara had the British ambassadors Stoddart and Conolly executed in 1842.

The Russians tried to legitimize their occupation actions through the discourse that the West expressed as an excuse for colonialism: "Civilizing the savages". The Russians also claimed that they organized military expeditions to abolish the slavery that prevailed in the Khanates. Foreign Minister Gorchakov used the discourse of unstable borders in a statement in which he tried to legitimize the invasions to the world public opinion in 1864 . The situation of Russia of the time was the same as that of civilized states that had relations with nomads lacking a developed state organization.... The statement "we have to dominate these nomads to prevent them from committing plunders and raids" 24 is the same as the discourse of "Islamic Terrorism" today, which is used as a justification for military interventions that are organized against Muslim countries and justify imperial action on security grounds.

Long focuses on the Chinese factor regarding Russia's tendency towards Turkestan. ${ }^{25}$ While Haryukov describes the Russian-British rivalry in the region, he points out that Russia learned the superior role of Islam in these regions by taking lessons from the Caucasian wars in the 19th century. It is an obligation for Russia to take Islamic traditions and customs into account and to be flexible or tolerant in terms of religion in the regions it conquers. The competition in the region results from very complex economic, commercial and other reasons. In fact, both the Russians and the British aim to strengthen their power over the regions that have been captured as a result of their economic, commercial and other interests over the region through their military power. It is stated that the purpose of the

\author{
${ }^{20}$ Потто 1887, s.1-5 \\ ${ }^{21}$ Çapraz 2011, s.52 \\ ${ }^{22}$ Çapraz 2011, s.55 \\ ${ }^{23}$ Zhukovskiı̆ 1915, s. 127 \\ ${ }^{24}$ Ferro, 2002 s.41 \\ ${ }^{25}$ Long $1874-1875$, s. 645, 647, 648
}


British missionaries operating in the region in the early 1800 s was actually to provoke the Muslim population in the Turkestan region against Russia. ${ }^{26}$

The 19th century was a period when merchants encouraged governments to expand, and during this period, Muscovite merchants forced the government to take military actions in Asia in order to create a market for themselves. In the report of the Ministry of Foreign Affairs dated 1838, the necessity of commercial relations with Turkestan was highlighted, and it was stated that "the basic foundation of our Central Asian policy is trade"27. Russia completed the occupation of Turkestan in almost 20 years. The political structure of Turkestan, which contained conflicts in itself, played a large part in this. The basin of the same culture (geoculture) could not display political unity ${ }^{28}$. At the end of the 18th century, the decisions of the Moscow administration, which might make people think that the social structure was based on religious groups and was an adaptation of the Ottoman "Millet system", were considered effective in the acceptance of the Tsarist authority. Fuller stated that the decisions taken by the Tsar to ignore ethnic differences and to accept religious differences enabled the development of religious ties between Muslim communities rather than ethnic ties, and that these groups remained loyal to the Tsarist monarchy despite the fact that nearly fifty wars were fought with the Ottoman Empire and four great wars with Iran over the last three centuries ${ }^{29}$.

\section{Figure 2: Turkestan Region}

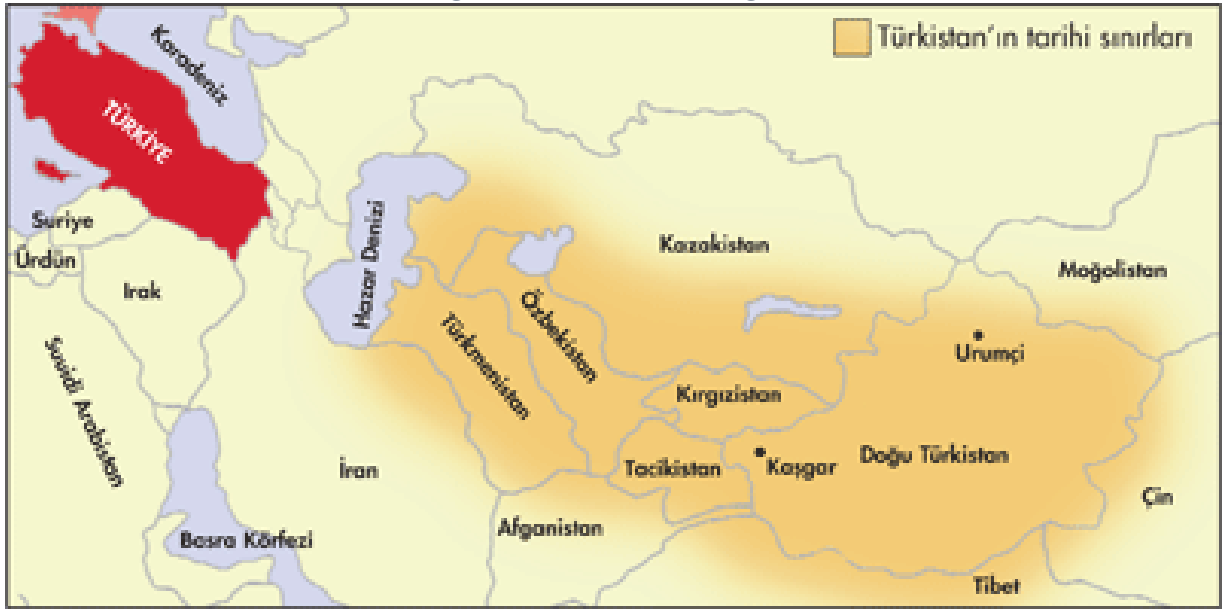

${ }^{26}$ Çapraz 2011, s.57

${ }^{27}$ Çapraz 2011, s.57

${ }^{28}$ Geoculture is a dominant political, social and cultural structure that dominates traditional thought and behavior, unlike identities in other fields and cultures, and therefore has a different geopolitical position. NESA 2009

${ }^{29}$ Fuller 2010, s. 185 


\section{Vefa KURBAN - Oğuzhan ERGÜN}

Having completed the unification process in AD 221, China continued to expand in Asia until 1911. At the beginning of the 15th century, China withdrew from global competition by burning its fleet that had reached Africa before the Europeans, and sometimes used punitive actions against Turkestan and Tibet by allocating its resources to prevent threats from the Northern region. ${ }^{30}$

Following its success in China-Turkmenistan natural gas pipelines and in other energy projects, China is striving to realize a very ambitious project called One Belt One Road. Its economic power has made China an important actor in the region. On the other hand, Russia desires to take advantage of the great economic potential of China. Russia's economic power and projects in the region are limited. Nevertheless, Russia is discussing regional security issues with China within the Shanghai Cooperation Organization established under the leadership of China. In 2004, Ambassador Wu Jianmin stated that "Chinese Foreign Policy has transformed from delicate diplomacy (responsive diplomacy - fanying shi waijiao) to proactive diplomacy (zhudong shi waijiao)" ${ }^{31}$ and Jin Liangxiang, one of the scientists of Shanghai International Research Institute, stated that the passivity that China had been maintaining in the Near East for years came to an end by leaving its place to active politics. ${ }^{32}$

Today, China's trade with such Central Asian Republics as Kazakhstan, Kyrgyzstan, Uzbekistan, Turkmenistan and Tajikistan is increasing day by day. In the global context, even during the pandemic period, China had the highest foreign trade surplus in the last 30 years ${ }^{33}$. However, this is met with concern by Russian security experts, disturbs Russia in that its backyard has become a "Yen" zone. Chinese expansionist policies should not be regarded as being limited to East Turkestan. In the report written and taught by General Liu Yazhou, political commissar of the National Defence University, the entire Turkestan region is targeted as an area of occupation and annexation.

"West of China is a great place. Tending towards the West (the Central Asian geography that includes East Turkestan) is not only a strategic option for us, but also our hope, even fate of this, our, generation. Its excellent location (close to the centre of the world) gives us a strong motivation. We should consider the West as the target region for advancement rather than a border region". ${ }^{34}$

Although Central Asia was tried to be controlled through containment policies in the U.S. foreign policy, direct internal policies were ignored for a long time. However, with the USSR's attempt to invade Afghanistan at the end of 1979, the opportunity to control the Persian Gulf and then the Indian Ocean was born for the USSR. The dissolution in the border zone affected the policies of the USA, and it started to make rebellion propaganda against the "atheist" Soviet government by addressing the peoples of Central Asia through the radio frequencies of Radio Liberty (Azatlyk Radiosy) and Radio Free Europe ${ }^{35}$. It gave

\footnotetext{
${ }^{30}$ Mann 2017, s.124

${ }^{31}$ Lin 2020 b.

${ }^{32}$ Liangxiang 2005, s. 3-10

${ }^{33}$ Bloomberg 2020

${ }^{34}$ Türkiye Enstitüsü 2021

35 Üzgel 2001 s. 37
} 
importance to strengthening economic, commercial and military ties through the multifaceted policy it started to pursue towards Central Asia after the 2000s.

The document paradigm titled "Defense Planning Guide", which had been published in 1992, reappeared in the US policies in 2018. This guide contains the essence of the "Bush Concept". It was advocated that the USA "relies on the military force with such a determination that will not make it hesitate to act alone when necessary to prevent attempts to establish new centers of power and to deter potential rivals from playing larger roles". "The necessity for Washington to maintain its superiority over the rest of the world by slowing down the development of any possible rival" 36 is somehow repeated. Any powerful country that is rising in the doctrine and determined to pursue independent foreign policy is considered as a threat and aggressive force against the USA, no matter how willing it is to get along with the USA for the sake of mutual interests. After Vladimir Putin came to power in Russia in 2000, Moscow's cooperation with neighbouring countries acquired a strategic dimension. It gave significance to strengthening economic, commercial and military relations especially through the multifaceted policy it began to pursue towards Central Asia. However, factors such as China's increasing influence in Central Asia through the Shanghai Cooperation Organization prevented the strategic moves of the USA from having direct impact on the region. ${ }^{37}$

When considered through the perspective of the actions that the USA and other related bodies carried out in Central Asia and Africa, and when the geography of the Caucasus and Turkestan becomes terrorised and anti-terror! export begins; serious political, military, social and economic threats will appear for Turkey, Iran, Pakistan, China and Russia. The spread of the idea of a radical predecessor in the Central Asian Turkic Republics and its further activation in Pakistan might result in a social and political identity crisis, turmoil and instability, and the effects of terrorism might create an internationalized environment for intervention. Furthermore, the Iron Silk Road, the "Silk Road Economic Belt" and the "China-Pakistan Economic Corridor", for all of which great hopes have been placed to achieve economic development and cooperation, will be at risk. Analysing the developments that have affected the futures of the South Caucasus and Turkey periodically and regionally will shed light on what might happen in the future.

\section{Prospective and Retrospective Discussion}

Events affecting Azerbaijan and the South Caucasus during the Soviet Union

\section{Period}

Following the October Revolution, which took place in Russia in 1917, the Bolsheviks tried to establish sovereignty in the Caucasus through land reform, guarantee of national rights and promises of independence. By 1920, the Red Army had invaded Armenia and Azerbaijan, and subsequently Georgia, and towards the middle of 1921, the Soviet power spread to a large part of the former territories of Tsarist Russia. ${ }^{38}$ Azerbaijani lands as of 1920 could be seen in the figure.

36 Tyler 1992

${ }^{37}$ Suyundikov 2020

${ }^{38}$ Suny 2006, s.497 
Figure 3: Azerbaijan 1920

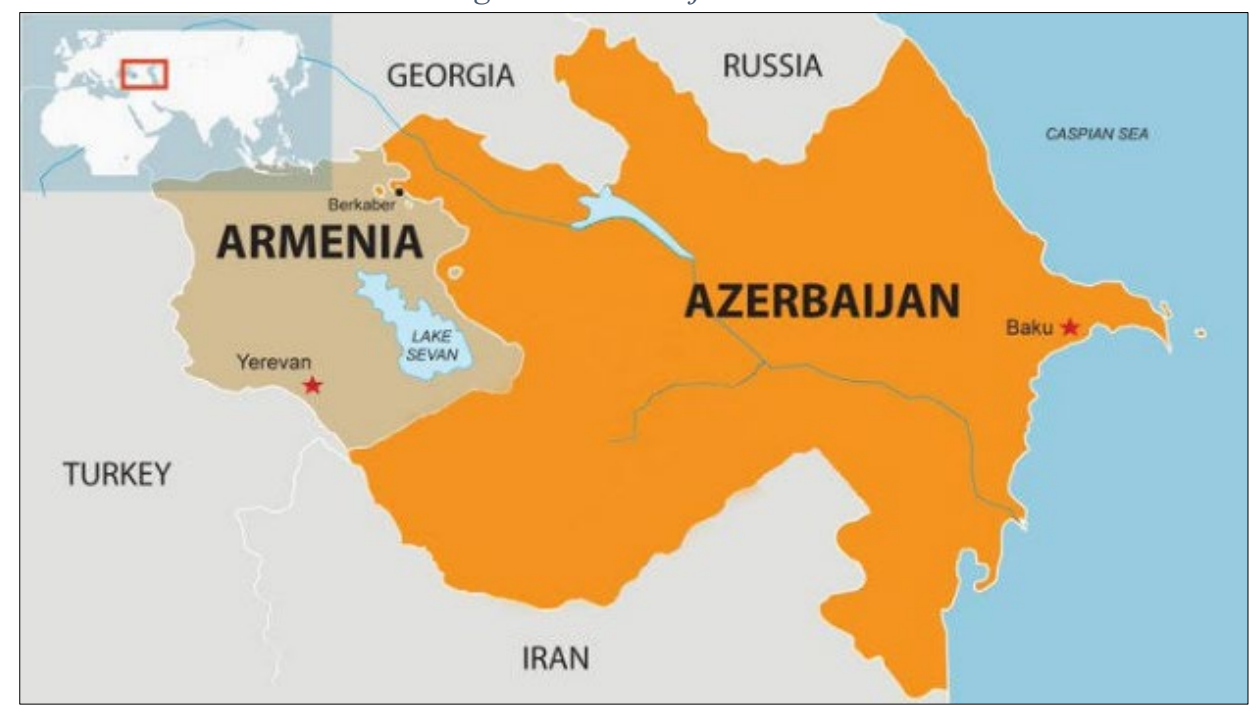

Source: Institute of Russian Studies

In 1922, the Union of Soviet Socialist Republics was established. There were fifteen republics forming the Union, one of them was the Azerbaijan Soviet Socialist Republic, another was the Armenian Soviet Socialist Republic. Since the establishment of the Soviet Union, the South Caucasus has been a geography open to ethnic conflicts. After the invasion of the South Caucasus by Bolshevik Russia, the leaders of the Armenian Soviet administration both conveyed Azerbaijan's claims regarding the Karabakh region to Moscow and expressed them in the Caucasus Bureau of the Russian Communist Bolshevik Party (RK(b)P). Upon these allegations, the Central Committee of the Azerbaijan Communist Party convened on June 27, 1921 and rejected the claims of the Armenian side and stated that the Karabakh region could not be separated from Azerbaijan. ${ }^{39}$ However, international issues emerged in the region after the Armenians claimed their rights, but this issue, like many other problems experienced throughout the seventy-year existence of the Soviet Union, was covered up.

Taken from Azerbaijan and given to the Armenians and referred by the simile of "Armenian Dagger", these lands witnessed a geopolitical disaster that Turkey and Azerbaijan went through. As a result, Turkey was separated from Turkestan, and Azerbaijan from Turkey and the Western World.

${ }^{39}$ Kurban ve diğerleri 2020, s. 184 
Figure 4: Seized lands

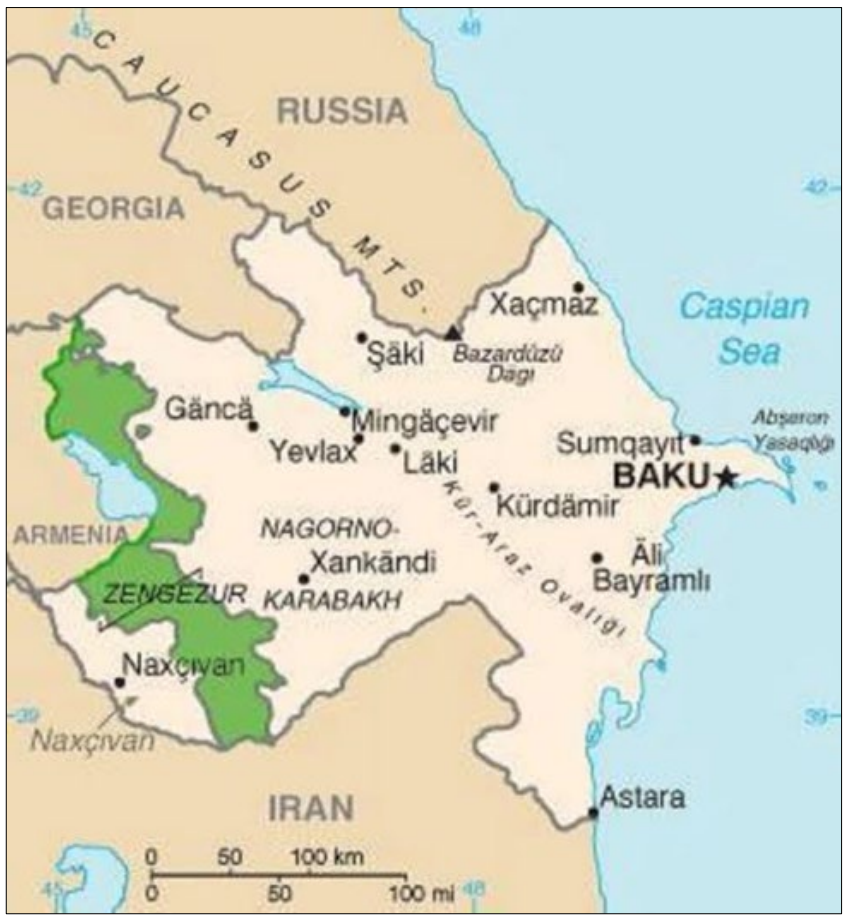

\section{Post-Soviet Period}

The Soviet Union ceased to exist with the Belovezhskaya Accord ${ }^{40}$ in 1991. It is certain that the period that started with Putin will have a special place in the Russian history. The answer given by (RF) President Vladimir Putin to the question of what event in the history of the country he would like to change in 2018 reveals the code of his geopolitical view, "the collapse of the Soviet Union"41.

In the context of the two decisions that started to go by Putin's own name and were composed as doctrines, preserving the status of the great power / global centre of influence took an indispensable part in the Russian foreign policy. This goal was included in all of the documents published by the Russian Ministry of Foreign Affairs in 2000, 2008 and 2016 regarding the "Foreign Policy Concept of the Russian Federation". The "Grand Strategy" continues to rely on implicit expansionism. Two important documents regarding the foreign and security policies were adopted by the Putin administration: National Security Strategy (April 21, 2000) and Foreign Policy Concept of the Russian Federation (June 28, 2000). In the document on national security, the security problems that Moscow was sensitive to in the post-Soviet period, which were stated in the Near Abroad Doctrine announced in 1993,

\footnotetext{
${ }^{40}$ Gorby 2020.

${ }^{41}$ Erol 2018.
} 


\section{Vefa KURBAN - Oğuzhan ERGÜN}

were once again emphasized. The rights of Russian citizens living abroad and the importance of using the Russian language were given special emphasis ${ }^{42}$. Among the prominent points in the "Near Abroad Doctrine", the most important ones related to what is being discussed here are the principles of protecting the minority and human rights of the Russian-speaking population in the region, declaring that Russia has vital interests in the former Soviet geography ${ }^{43}$, deploying Russian soldiers in neighbouring countries as "Peacekeeping Forces" and thus creating a security belt in the immediate vicinity of Russia $^{44}$. The possibility that Putin ${ }^{45}$, who adopts pragmatist Eurasianism, might carry out classical colonial policies such as granting Russian Federation citizenship to the population settled in the Karabakh region (example of Abkhazia and Ossetia) ${ }^{46}$ or settling people of Russian origin in the region should not be ignored.

Javakheti (Akhaltsikhe) Region in the South Caucasus, Georgia, where the Armenians constitute the majority, is one of the reasons behind Russian intervention in Georgia. Kissinger's prediction for the strategic architecture of the Russian Federation is that if it fails to conquer Ukraine, it will gravitate to establish the Asian Empire ${ }^{47}$. Although the fact that this clearly happened through hard power will be affected by the negative attitudes of other actors who are partly in need of independent structures in the region, geocultural developments have reached a level that might cause the Russian Federation to be pushed into a survival problem. However, it has always had the potential to trigger social fault lines in the same region.

Halbach argues that the birth of the former Soviet peoples' own states moved away from the Soviet ideology that was hostile to religion and was linked to the old "religion" and "national rebirth" phenomenon. The politicization of religion in the research and analysis conducted has also become a problem in the Christian parts of the post-Soviet region - for example, in the South Caucasus. This relationship is very evident in places where the dominant religious community exists especially in the form of an old regional or national church. For instance, as Armenia and Georgia moved away from secularism, questions about whether the national meaning of religion strengthened or not increased. As in the case of Georgia, academicians and civil society representatives issued warnings about the emergence of "religious nationalism"48. Halbach's findings indicate that "religious rebirth" in Muslim regions helped them to establish connections with the Islamic world outside stretching from Central Asia to Azerbaijan in the South Caucasus. Although varying from region to region, radicalization was observed and militant forces emerged. However, the Azerbaijani society is largely based on secular nationalism, despite complete rediscovery of the Islamic tradition ${ }^{49}$.

\footnotetext{
${ }^{42}$ Sönmez 2010, p. 8

${ }^{43}$ Rubinstein 1976, p.43

${ }^{44}$ Danilov 1996, p.142

${ }^{45}$ Sönmez 2010, p. 69

${ }^{46}$ Gülbey 2021.

${ }^{47}$ Brzezinski 2005, p. 123

${ }^{48}$ Halbach 2016 p. 5

${ }^{49}$ Halbach 2016 p. 5
} 
Religious structure is not taken as a basic reference in the studies on conflict and cooperation in the region. For example, Armenia, the oldest Christian country, maintains good neighbourly relations with the Islamic Republic of Iran. On the contrary, in the postSoviet period, despite the unity of belief, Azerbaijan entered into largely tense relations with Iran. On the other hand, Georgia fought against Russia while developing closer relations with Muslim Azerbaijan compared to Armenia, which is a Christian country. Ethno-territorial motives are brought to the fore in the Azerbaijan-Armenia conflict, rather than religious factors. It is claimed that under President Putin administration, the cooperation aimed at "near abroad" has increased in the politics between the state and the church in Russia. In this collaboration, Orthodox traditionalism is propagated as an exit from the alleged Western collapse. ${ }^{50}$

2013 research results of Caucasus Research Resource Center (CRRC) show that when the religious policy of the State comes into question, Georgia is the least regulatory state and Azerbaijan is the state with the strongest control over the religious field ${ }^{51}$. In the surveys conducted in Armenia, it was stated that approximately $91 \%$ of the people are affiliated with the Armenian Apostolic Church. The survey results also revealed that the rate of those who stated that religion is "very important" in their life was $56.3 \%$, and the rate of those who stated "quite important" was $30.6 \%$. The percentage of those who said "never" to the question about communicating with Sunni and Shiite Muslims was between $90.6 \%$ and $90.9 \%{ }^{52}$. The rejection of inter-communal communication could be a precursor of new provocations in many areas.

Slavism and Orthodoxy are at the top of the main arguments that have been used for centuries in Russian foreign policy. It forms the basis of many irredentist ${ }^{53}$ discourses ranging from that of third Roman Empire to that of reintegrating Istanbul to Christianity ${ }^{54}$. Orthodoxy and Slavism are included in the rapprochement policies in the area extending from the Balkans to Greece and Southern Cyprus. As a matter of fact, it is claimed that Lavrov, who visited Serbia and the Serbian section of the Republic of Bosnia and Herzegovina in the past, is a politician who advocates that Bosnia-Herzegovina, Montenegro and North Macedonia should be under the influence of Russia just like Serbia. It is among the recurring claims that Russia interfered in the general elections in Montenegro through the Serbian Orthodox Church ${ }^{55}$. The overseas Orthodox Community will always expect Russia to prioritize the Armenian Orthodox community, for which Russia has played the role of Protector for years, rather than Azerbaijan.

${ }^{50}$ Halbach 2016 p. 6

${ }^{51}$ CRRC 2003

52 ARDA 2020

${ }^{53}$ Irredentism, or liberalism, is a word of Italian origin and refers to the idea of the unification of a state with its people living outside the borders of that state although there is unity of language, religion, ancestry and culture.

${ }^{54}$ Kissinger 2016, p.64

55 Yaşın 2021 "In Montenegro, in October 2016, 2 Russians and 2 Montenegrin politicians who were held responsible for the coup attempt taking place on the day of the general elections, the former Gendarmerie commander of Serbia and 9 citizens of Serbia were sentenced to a total of 69 years in prison". 


\section{Vefa KURBAN - Oğuzhan ERGÜN}

The concept of Political War that is put forward today aims at centrifugal forces. As a US concept, Political War includes taking political, informatics, military and economic measures in a certain spectrum to influence, coerce, intimidate, and weaken so that a state could protect the interests of its own, friends and allies against a number of actors. Many of these measures are often referred to as "political war" as a whole. ${ }^{56}$ "Political war often exploits common ethnic or religious ties or other internal dynamics. Political war is cost efficient and replaces traditional conflicts". ${ }^{57}$ Although different conceptualizations are used, China or Russia produce and implement similar concepts. The developing conjuncture has triggered ethnic fault lines and hybridization in international politics. Alliances began to host ad-hoc coalitions, and kinship relations in one region and hostile in another became widespread.

Central Asia is witnessing the renewal of the "Big Game" due to its possession of large hydrocarbon reserves (oil and gas) and minerals such as uranium and its strategic location connecting main markets (Europe and Asia). Geopolitical and geoeconomic shaping has not yet been completed, but architectural initiatives are ongoing. Central Asia is a region providing certain geoeconomic advantages to countries or multinational corporations with specific regional or global goals based on their own interests or the need to neutralize other nations or companies that rival them. According to the data of 2018, four of the ten largest uranium ore deposits in the world are in Kazakhstan. 15.4\% of the world's production takes place in these mines. Uranium mine capacity is 29.764 tons, while it is only 4.600 tons in Russia, one of the leading nuclear powers. It is 3000 tons in Uzbekistan. (The total capacity in the world is calculated as 75.514 tons) ${ }^{58}$. It is stated that Turkmenistan, which possesses $10.1 \%$ of the world's natural gas reserves, ranks fourth in the world in terms of proven gas reserves. ${ }^{59}$ In 2019, while 5 billion cubic meters of natural gas was exported to Russia annually, the export of Turkmen gas to China was expected to reach 60-70 billion cubic meters annually. ${ }^{60}$ The People's Republic of China is currently the biggest importer of Turkmen natural gas ${ }^{61}$. Billions of cubic meters of energy raw materials are supplied to the international pipeline of Turkmenistan-Uzbekistan-Kazakhstan-China. Russia is the country with the most assets in the new Kyrgyz and Tajik projects.

It was reported that SOCAR Trading, a subsidiary of the Azerbaijan State Oil Company, signed a contract for the purchase of Turkmen oil produced by Turkmenistan. This tender revealed that SOCAR Trading beat the giants of the oil market such as ENOC, Vitol, Rosneft, Lukoil and Trafigura. According to the information provided, Eni Turkmenistan plans to deliver 30.000-40.000 tons per month from Ekerem (Turkmenistan) in 2021. While Turkmen crude oil had been exported through the Baku-Tbilisi-Ceyhan (BTC) oil pipeline since mid-2010, after the Azerbaijani logistics company responsible for deliveries lost the tender to a Russian company in 2018, Turkmen oil started to enter the

\footnotetext{
${ }^{56}$ Ergün 2020, p. 222.

${ }^{57}$ Robinson et.al 2018.

${ }^{58}$ World Nuclear Association 2021

${ }^{59}$ Enerji Portali 2019

${ }^{60}$ T.C Ticaret Bakanlığ $12021 \mathrm{a}$

${ }^{61}$ News Central Asia 2021
} 
world markets through Russian channels. However, the Russian firm did not have a sufficient tanker fleet for transportation. Therefore, the supply of Turkmen oil to the world markets has significantly decreased. The situation undoubtedly affected the revenues of foreign oil companies in Turkmenistan. While it is predicted that Turkmenistan supply approximately 1 million tons of crude oil annually, Azerbaijan has also become a serious supplier in addition to its production. The annual volume of the contracts of SOCAR Trading for the supply of various types of oil from Turkmenistan, Russia and Kazakhstan through BTC in the Caspian region is over 4 million tons ${ }^{62}$. Gas and petroleum products reaching the Mediterranean from the Tovuz region via the BTC line, and the natural gas reaching Europe through the TANAP (Trans Anatolian Natural Gas Pipeline Project) affect Russian revenues.

Figure 5 Energy Production Amounts of Eurasia 2018

\begin{tabular}{|c|c|c|c|c|c|c|c|c|}
\hline & $\uparrow$ Total & Coal & Naturalgas & Nuclear & Hydró & Wind, solat, etc. & Biofuels and waste & Oil \\
\hline & ktoe & ktae & ktos & ktoe & ktoe & kloe & ktos & ktoe \\
\hline Total Eurasia & 939509 & 161992 & 506765 & 54778 & 21855 & 303 & 9147 & 187387 \\
\hline Russian Federation & 759327 & 119587 & 413707 & 53637 & 16435 & 185 & 8579 & 148281 \\
\hline Kazakhstan & 75758 & 37516 & 18619 & & 894 & 73 & 75 & 18880 \\
\hline Uzbekistán & 46393 & 2442 & 39374 & & 507 & & 4 & 4100 \\
\hline Turkmenis:an & 27646 & & 21350 & & & & 10 & 6561 \\
\hline Azerbaijan & 14378 & & 9300 & & 152 & 10 & 111 & 4918 \\
\hline Georgia & 4855 & 303 & 2045 & & 855 & 28 & 271 & 1274 \\
\hline Kyrgyztan & 4556 & 1038 & 279 & & 1231 & & 2 & $-\pi^{70}$ \\
\hline Tajjikistan & 3513 & 1105 & 47 & & 1582 & & & 984 \\
\hline
\end{tabular}

Source: https://www.iea.org/regions/eurasia

\section{Problems of Armenia and Its Power to Solve Them}

Armenia does not have the power to solve the problems it produces regarding Azerbaijan and the Turkic World. One of the basic qualities sought in the political conflicts that have turned into war, namely the conventional hot war, is that both sides operate within the framework of a strategic plan.

Population (2019)

\begin{tabular}{|c|c|c|}
\hline Azerbaijan & 10.023 .318 (Male 5.003.653) \\
\hline Armenia & $2.957 .73(1.383 .300)$ & \\
\hline
\end{tabular}

${ }^{62}$ T.C Ticaret Bakanlığı $2021 \mathrm{~b}$ 


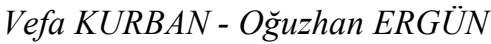

Population, Male (rate in total population) (2019)

\begin{tabular}{|c|c|c|}
\hline Armenia & $47 \%$ & \\
\hline Azerbaijan & $50 \%$ & \\
\hline
\end{tabular}

Source: Population, male - Azerbaijan | Data (worldbank.org), Population, total -

Armenia | Data (worldbank.org), Date Accessed 10.01.2021

National Income (2019) (in constant USD rate of 2010)

\begin{tabular}{|c|c|c|}
\hline Armenia & $13.996 .188,67$ & \\
\hline Azerbaijan & $58.937 .036,21$ & \\
\hline
\end{tabular}

Source: GDP (constant 2010 US\$) - Armenia | Data (worldbank.org)

Figure 6: Comparison of National Income

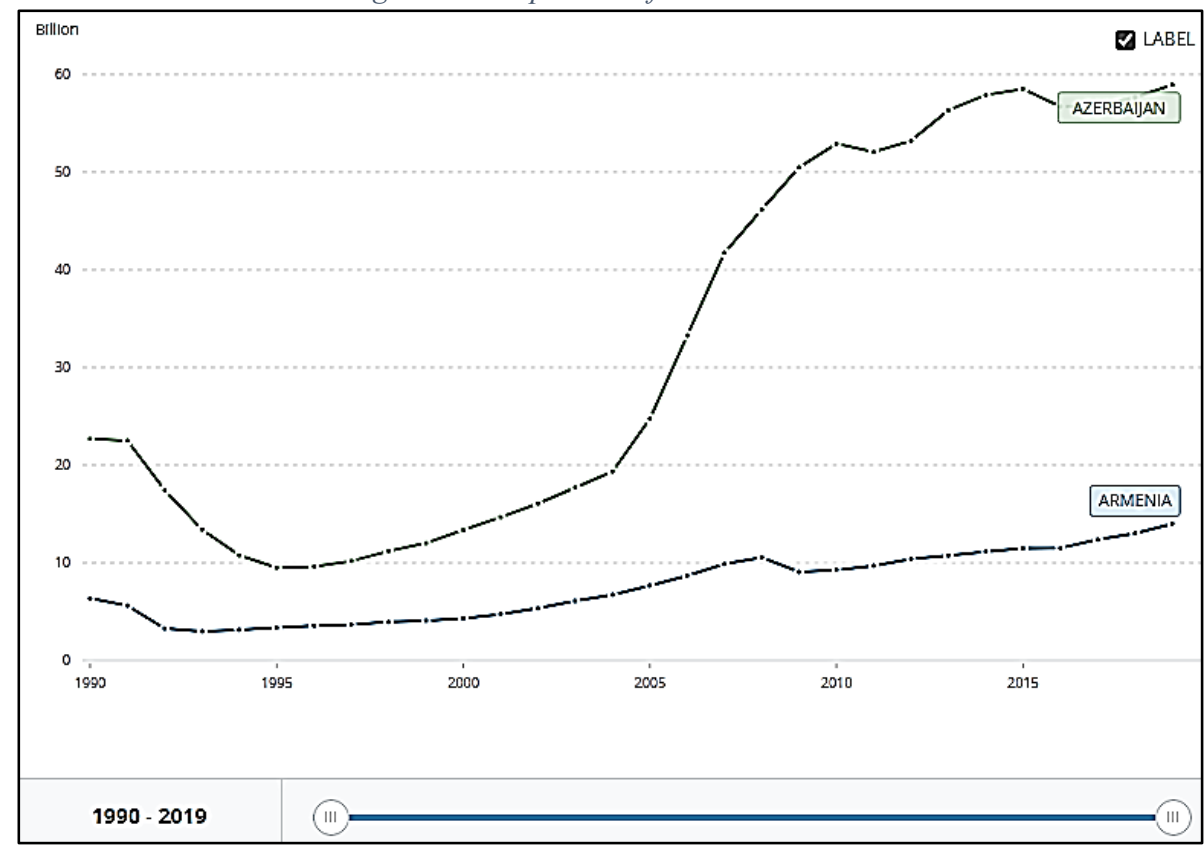

Source: WB, GDP (constant 2010 US\$) - Armenia, Azerbaijan | Data (worldbank.org)

After the Soviet Union, the ethnic conflicts, which had already existed and turned into bloody actions as of 1987, intensified in the South Caucasus region. Especially as of 
February 1988, the disputes between Armenia and Azerbaijan in the Nagorno-Karabakh territories continued with intense hot clashes. ${ }^{63}$

After the Armenian population increased within the demographic structure of the Caucasus, the Armenian actions in the region were supported by foreign powers. Before Nagorno-Karabakh was invaded by Armenia, when Gorbachev declared the policy of "Glasnost and Perestroika", Armenia brought the unification with Nagorno-Karabakh on the agenda of the USSR. The aim of Armenia was fulfilled after the dissolution of the USSR. Russia provided all kinds of military support to Armenia in the ArmeniaAzerbaijan war, and ensured the occupation of Azerbaijani territories by Armenia. ${ }^{64}$

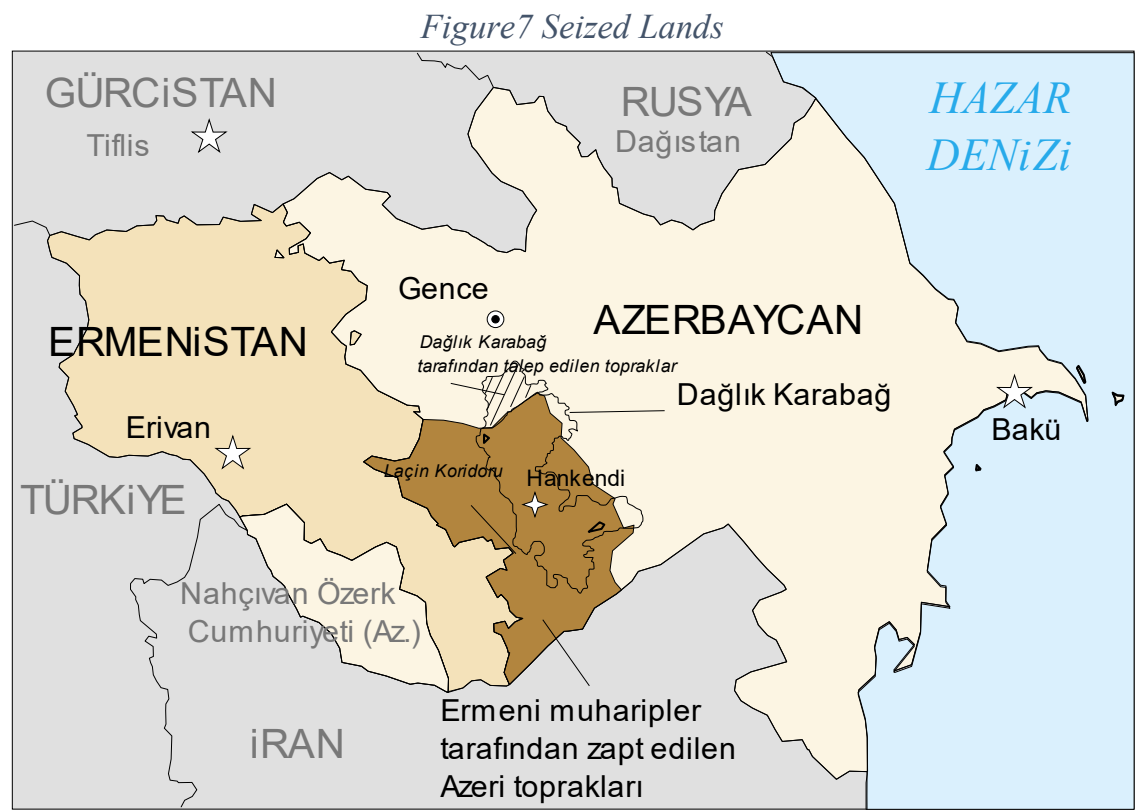

Just as a similar issue was about to appear in Nakhchivan; Turkey compelled Russia to be cautious in this regard by using its guarantor status it had achieved with the treaties of Kars and Moscow. ${ }^{65}$

With the collapse of the Soviet Union and the bipolar world, such states as Azerbaijan, Armenia and Georgia in the South Caucasus gained their independence, and they found themselves on a new geopolitical scene. On the other hand, American President W. Bush began to redesign the US foreign policy at that time. At that time, Russia was facing with its own internal socio-economic issues. ${ }^{66}$

\footnotetext{
63 İbrahimov 2020.

${ }^{64}$ Kurban ve diğerleri 2020 , p. 123

${ }^{65}$ Şimşir 2011, s.175; Kurban ve diğerleri 2020, p. 123

${ }^{66}$ Gafarlı ve diğerleri 2016.
} 


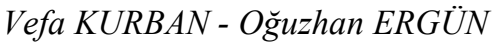

Claiming that Russia should defend the Russian population and heritage in the former Soviet republics, Eurasians have argued since 1993 that Russia should protect its interests in the former Soviet republics with more realistic approaches and take responsibility in these countries. Yevgeny Primakov, who was appointed as the Minister of Foreign Affairs in 1996, defined the Russian foreign policy as "balancing the stance against American hegemony with the Eurasian and CIS axis". In his work "The World Without Russia", he stated that the Caucasus is the red line and that the lack of trust between Russia and NATO led to this approach. ${ }^{67}$

In the 1990s, the Armenian army occupied $20 \%$ of the unarmed Azerbaijani territories and carried out Khojaly genocide against the Azerbaijani Turks in the region, which was described as the most extensive massacre of that period. International Organizations and society did not react properly.

In order to solve the problem in the region, it was handled within the framework of the OSCE Minsk group, plans were made, but not implemented. In an interview with the former US Representative to the OSCE, John J. Maresca, he listed the basic conditions for lasting peace in the region as follows:

1. Continuation of the autonomous status of Nagorno-Karabakh under the sovereignty of Azerbaijan;

2. Issuance of some kind of guarantee for the security of Nagorno-Karabakh;

3. Withdrawal of the Armenians from the Azerbaijani territories they occupied;

4. Special arrangements for the Lachin corridor and Shusha (with similar arrangements between Azerbaijan and Nakhchivan) to allow the Armenians of NagornoKarabakh to enter Armenia;

5. Arrangements to allow most refugees on both sides to return to their homes;

6. Massive international efforts. ${ }^{68}$

Evaluating the tension between Azerbaijan and Armenia, Colonel Viktor Baranets, military expert of the newspaper "Komsomolskaya Pravda", stated: "The attempts of any state to be peaceful in this conflict can only be welcomed. It is very important to save even one person's life". He also added: "Yes, Belarus has international experience in mediating the parties and Minsk can be a judge in this difficult process" 69 . However, apparently, the Minsk group had not done its job for about 30 years.

In addition, following the collapse of the Soviet Union, Turkey returned to the Eurasian geopolitics as a great power.

After Putin took office, one of the main goals of Russia was to re-establish and maintain its sphere of influence in the former Soviet Union, including the South Caucasus region, and to prevent the expansion of the EU and NATO into the South Caucasus and at the same time the encirclement of Russia by the West. ${ }^{70}$

George Friedman, the founder of Stratfor, a US private intelligence platform, emphasized that the West needs to purchase energy from Russia, which is an energy

\footnotetext{
${ }^{67}$ Gaffarl1 2011.

${ }^{68}$ Blair 2020.

${ }^{69}$ Баранец 2020.

${ }^{70}$ Gafarl1 et.al 2016.
} 
exporter today, more than Russia needs to sell energy to the West, and through a political perspective, America's need for Russia is above Russia's need for America. ${ }^{71}$

\section{Appointment of Sergey Lavrov as Foreign Minister of Russia in 2004}

Born in 1950, and graduating from Moscow State Institute of International Relations (MGIMO) in 1972, Lavrov was assigned to the Russian Embassy in Sri Lanka after graduation, served for the USSR Ministry of Foreign Affairs between 1976-1981, and worked as a Permanent Representative of the Russian Federation to the United Nations in New York between 1994-2004. As of March 9, 2004, Lavrov was appointed as the Foreign Minister of the Russian Federation. ${ }^{72}$ Rumours are circulating about Sergey Lavrov's birthplace and surname. ${ }^{73}$ While some Russian and Georgian sources wrote that Lavrov is originally an Armenian from Tbilisi and his surname is not Lavrov, but Kalantarov or Kalantarian ${ }^{74}$, the Russian News Agency TASS preferred not to share any information on this issue. ${ }^{75}$

Upon the intensification of hot conflicts between Armenia and Azerbaijan in April 2016 following the provocative activities of the Armenian side, the OSCE Minsk group co-chairs "took action", some so-called steps were taken towards the solution of the problem, the issue was discussed at the table and the new proposals on the table were named as the "Lavrov Plan". Although the Armenian side did not object to the plan, no concrete steps were taken, and Armenia continued the occupation process. ${ }^{76}$

Hakob Badalyan, commentator of the Armenian Public Radio, said, "That the Lavrov Plan is about the surrender of the Armenian regions to Azerbaijan in the form of five or seven regions is probably true only from an external perspective. Apparently, Russia needs this to Eurasianize Azerbaijan. Are they naive enough to think that Turkey would let them Eurasianize Azerbaijan? (Referring to the Russians) Moscow is not so naive, Russia needed regional events for a stalemate that would increase the likelihood of military action and this would lead to a high likelihood of Russian military intervention ... Who should Armenia have turned to? Of course, to Russia"77.

\section{April 2016 War}

In March 2016, Friedman, President of the Stratfor Organization, stated in his interview with Business Insider that "Be ready for war". ${ }^{78}$ Soon after the announcement, the South Caucasus region fell into dispute again.

\footnotetext{
${ }^{71}$ Friedman 2020.

${ }^{72}$ Government 2020.

${ }^{73}$ In order to understand Sergey Lavrov's attitude in ethnic and regional conflicts between Armenia and Azerbaijan, there has been a need to share information about Lavrov's national affiliation.

${ }^{74}$ ИНОСМИ 2020.

75 Tass 2020.

${ }^{76}$ Aslanli 2020.

77 Armradio 2020 "Lavrov'un planı ortaya çıkmış ve yırtılmıştır", https://tr.armradio.am/2020/09/04/lavrovun-plani-ortaya-cikmis-ve-yirtilmistir/, (11.12.2020)

${ }^{78}$ Friedman 2020b.
} 


\section{Vefa KURBAN - Oğuzhan ERGÜN}

Despite the ceasefire agreement signed between Armenia and Azerbaijan in 1994, which is a period where the ceasefire was violated many times, hot clashes took place in the Karabakh region between April 2, 2016 and April 5, 2016. Having lasted for 4 days, this war was actually different from the others in terms of its size, characteristics and most importantly, its results. The four-day war was halted when the ceasefire agreement was signed in Moscow between the General Staff of the two countries. The conflict actually came to an end following Dimitri Medvedev's visits to the capitals of both countries and the active intervention of Russia in the event. ${ }^{79}$

Despite the casualties, the four-day war could be considered an important success for Azerbaijan because it managed to reclaim three hills of strategic importance in both the northern and southern regions of Karabakh after a long period, which provided great gains and military advantage and left a positive psychological effect at the same time ${ }^{80}$

The Four Day War had political consequences as well as military and psychological consequences. In fact, due to this war, the attention of the world public opinion was drawn to an important problem that was described as a "frozen conflict" and that the Armenian side especially wished to be forgotten.

As it is known, the negotiations and solution process of the Nagorno-Karabakh conflict are handled by the OSCE Minsk Group, of which Russia, France and the USA are the co-chairs. However, the OSCE Minsk Group have not taken an active step towards the solution of the Nagorno-Karabakh conflict, and it is obvious that the co-chairs of Russia and France prioritise different geopolitical goals and are not working for the solution of the issue, on the contrary, they function to keep the conflict unsolved.

While evaluating the US perspective on these conflicts in the South Caucasus region in 2016, George Friedman stated, "wars in remote areas do not attract the attention of other states, but it should not be forgotten that all the wars that the USA participated in after World War II were in remote places". He also highlighted that on the one hand, "the USA tends to be involved in exactly these kinds of conflicts", on the other hand, "the USA is not yet interested in the results of the conflict in the region". ${ }^{81}$

During the Four-Day War, which was going on with the victory of Azerbaijan, on April 3, 2016, the President of the Parliamentary Assembly of the Council of Europe (PACE) Pedro Agramunt's call for the withdrawal of the Armenian armed units from the occupied territories of Azerbaijan in accordance with the resolutions of the United Nations Security Council (UNSC) was of great importance in that it emphasized that the current situation in Nagorno-Karabakh is actually an occupation. ${ }^{82}$

\section{Dynamics That Brought Nikol Pashinyan to Power in 2018}

On May 8, 2018, the Financial Times wrote that "Nikol Pashinyan, the deputy of the opposition party, whose name had not been well-known until two months ago, became

\footnotetext{
${ }^{79}$ Lenta 2020.

${ }^{80}$ Tuncel 2016.

${ }^{81}$ Friedman 2020.

${ }^{82}$ Tuncel 2016.
} 
the Prime Minister of Armenia", and he stated during the interview that big changes awaited his country after a period of almost 20 years of recession. ${ }^{83}$

When the protests launched by Pashinyan in April 2018 led to Sargsyan's resignation, Pashinyan stated that the opposition had actually been planning these protests for nearly a year, i.e. since the opposition won only 9 seats in the parliamentary elections. Pashinyan also emphasized that the old government "lost power because they did not see the obvious, and now it is impossible for them not to see the facts". In those days, another leader of the opposition, Armen Grigoryan confessed that "At first, people criticized him a lot, even I. However, when the protests started, the activists realized that he was the best in us".

In the first months of Pashinyan's rule, Armenian politologist Mikayel Zolyan said, "Armenia does not want to lose its ally Russia. In addition, Armenia has problems that cannot be solved and cannot be simplified with Azerbaijan due to Nagorno-Karabakh. Pashinyan brought Armenia into an irreversible change... This is a completely different paradigm". ${ }^{84}$

When Pashinyan came to power in 2018, he made promises that he would establish a "New Armenia" far from corruption and poverty, avoid unilateral concessions in the Karabakh negotiations, and such concessions would be rejected.

When Sargsyan announced his intention to stay in power, the opposition in Armenia closed down important highways in the city, and declared a "velvet revolution". Nikol Pashinyan became the main face, leader and strategist of the "velvet revolution". Contrary to the predictions of experts, this movement in Armenia quickly gained the characteristic of a nationwide grassroots movement. ${ }^{85}$

While Pashinyan was acting as a deputy of the opposition, he began to draw attention when he criticized Armenia's pro-Russian orientation and questioned the benefits of joining the Eurasian Economic Union. Russia, on the other hand, displayed a neutral behaviour in those days and followed this change of power in Armenia without supporting the previous regime. ${ }^{86}$

Although Armenia does not seem to have broken out of the Russian orbit in the international arena, Pashinyan's activities in the country caused Russia to perceive it differently. The arrest of General Yuri Khachaturov ${ }^{87}$, who was serving in Moscow, and former President Robert Kocharyan ${ }^{88}$ was met with a harsh reaction from Russian Ministry of Foreign Affairs. Both arrests were actually about the domestic policy of Armenia, not about its foreign policy, the issue was the murder of protesters on March 1, 2018.

However, the events were not limited to this. Every move Pashinyan carried out, such as the searches made in the Russian railways office in Yerevan, and the assignment

\footnotetext{
${ }^{83}$ Financial Times 2020

${ }^{84}$ Седдон 2020

85 Атанесян 2020

${ }^{86}$ Пашинян d 2020

${ }^{87}$ RBC 2020

${ }^{88}$ DW 2020
} 


\section{Vefa KURBAN - Oğuzhan ERGÜN}

of activists affiliated with the ${ }^{89}$ Soros $^{90}$ Foundation to senior positions, was actually perceived as Armenia's orientation towards the West.

On the other hand, they started to call Pashinyan the Navalny of Armenia. Indeed, Alexei Navalny himself praised the Armenian revolution and said, "I just applaud Pashinyan". ${ }^{91}$

As soon as Pashinyan came to power, he defined Karabakh as a priority of his administration and first visited Khankendi (Stepanakert). ${ }^{92}$ Pashinyan decided to persuade the OSCE Minsk Group co-chairs and representatives of the so-called NagornoKarabakh Republic, who did not recognize the former, to return to the negotiating table.

The Minsk Group co-chairs of Russia, France and the US did not show any interest in this proposal, and confirmed that they did not intend to change the format. However, Pashinyan continued to insist. This situation did not prevent the dialogue with the Azerbaijani President Ilham Aliyev. In the first year of the regime change in Armenia, they met twice at international conferences. And it turns out that the content of these conversations will remain subject to speculation and manipulation forever. After this process, ceasefire violations started to increase..$^{93}$

During Pashinyan's visit"4 to Khankendi in the summer of 2019, he said "NagornoKarabakh is Armenia, period" ${ }^{\prime 95}$, which caused great reactions in Azerbaijan, ${ }^{96}$ and this situation was interpreted as Armenia avoided negotiations. In reply, Ilham Aliyev said, "Karabakh is Azerbaijan and exclamation mark". The last meeting before the hot clashes between Pashinyan and Aliyev took place at the Munich Security Conference in February $2020 .{ }^{97}$

\section{War of September 27, 2020 -Last Battle and Cemre!}

On September 27, 2020, after Armenia's missile attack on Tovuz, a civilian settlement of Azerbaijan, it succeeded in taking the occupied territories back after a 44day war by launching all-out counter-attack. On the next day after the war started, Sergey Markedonov, one of the strategists of the Moscow State Institute of International Relations (MGIMO), stated: "Since Azerbaijan considers itself defeated, it is pursuing an active policy in the region, and it is not satisfied with the continuation of the current status quo. On the other hand, Armenia is satisfied with the current situation. As long as the control of the region does not pass to Baku and as long as the current situation continues, an illusion emerges as if the region belongs to Armenia". 98

\footnotetext{
${ }^{89}$ Kommersant 2020

${ }^{90}$ Değer defines SOROS as "international financial speculator". Değer, 2018, s. 81.

${ }^{91}$ Навальный 2021

92 Пашинян 2020c

${ }_{93}$ Атанесян 2020

94 Пашинян 2020а

95 Пашинян 2020c

${ }^{96}$ Мкртчян 2020

${ }^{97}$ Политика 2019

${ }^{98}$ Маркедонов 2020
} 
During the 44-day war, Russia supplied weapons to Armenia. This was clearly confirmed by the data of Russian military flights. Following the war, a General in the Armenian army said that Russia "supplied Armenia with weapons of which we could not even dream". The general even announced the names of some types of weapons very clearly: One of them was the Pole-21 electronic systems, which could inactivate the Turkish unmanned aerial vehicles called Bayraktar TB-2, which had enabled Azerbaijan to dominate the sky over Karabakh for four days. The BBC correspondent to the Armenian Ministry of Foreign Affairs confirmed that the critically needed air defence and electronic warfare equipment was procured from Russia. While the war was still going on, Vladimir Putin said in an interview that "Russia has responsibilities to Armenia and has fulfilled these responsibilities". However, he underlined that there is no legal ground for Russia to consider this situation as the duty of protecting not only Armenian territories but also Karabakh. Putin emphasized that even Armenia itself did not recognize the independence of Nagorno-Karabakh.

During the days the war was going on, Prof. Dr. Hüseyin Bağc1 commented that "I think it will be the most appropriate policy for Azerbaijan to move its army as far as possible, that is, until it re-annexes all the borders to its own lands, until it annexes 20 percent of the occupied lands completely to its own borders. He also underlined that Armenia is a country under the protection of Russia and its borders are protected by Russian soldiers, but what Azerbaijan did was to pursue the UN policy of protecting and self-defending its own territory within the framework of Article 51. ${ }^{99}$

Pavel Felgenhauer, a Russian military expert, also made an interesting remark regarding the effectiveness of the Russian arms supplied to Armenia during the NagornoKarabakh war. Felgenhauer: "The Nagorno-Karabakh war also brought up the issue of the effectiveness of Russian weapons used by the Armenian side. The Iskander missile system, through which Russia scared Europe, could not prove itself in this war failing to hit a single target". ${ }^{100}$

According to the official statements issued by Azerbaijan after the war, 2783 Azerbaijani soldiers were martyred while 103 soldiers would be identified through DNA analysis, and more than 100 soldiers were missing.

Azerbaijan won the 44-day war, which had started on September 27, 2020, and ended when Armenia signed the surrender document on November 10, 2020. Azerbaijani soldiers showed determination and perseverance in this war.

\footnotetext{
${ }^{99}$ Saltan 2020

100 Фельгенгауэр 2020
} 


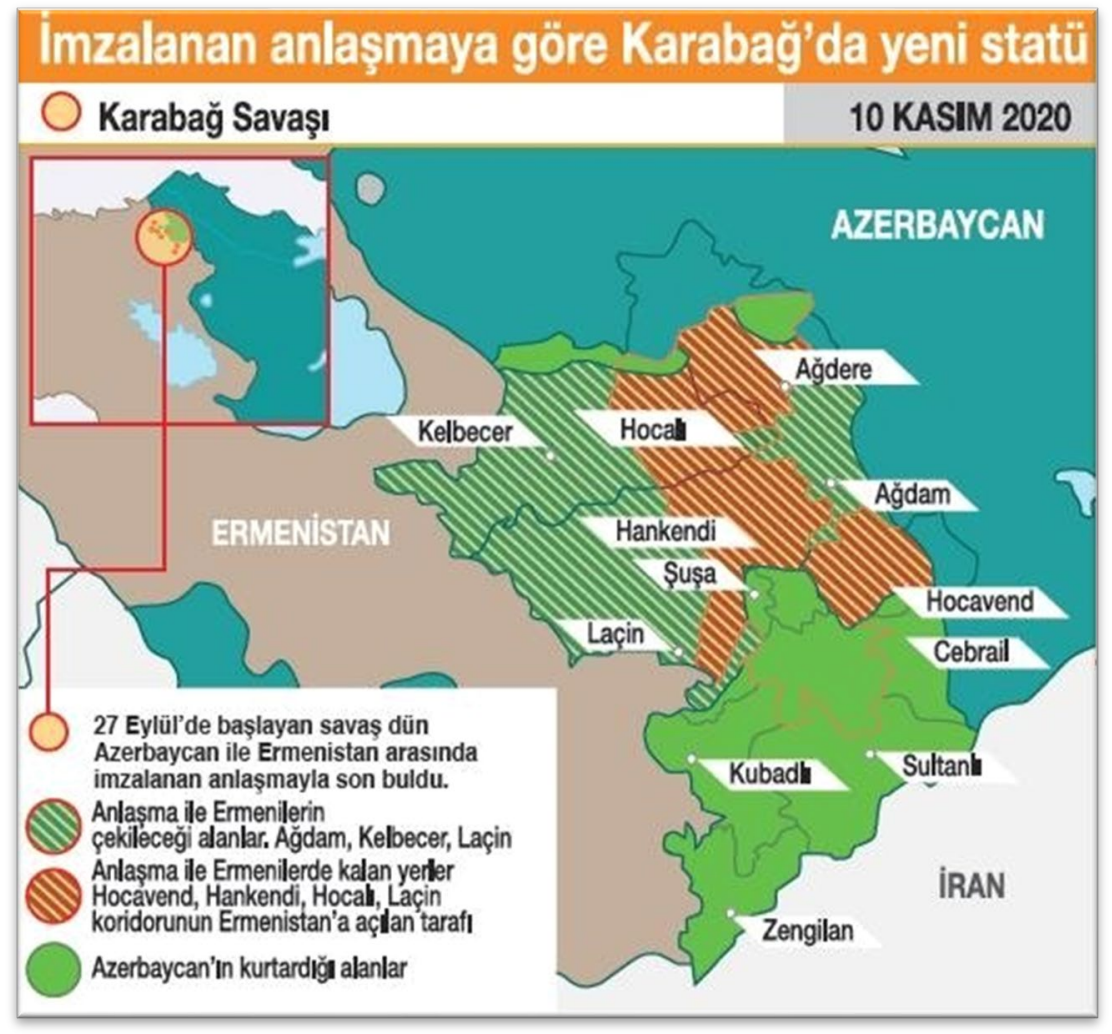

Source: Sabah Gazetesi, 11.12.2020

Military and technological superiority sustains diplomacy to a certain extent. With the Peace Deal signed following the war, it was decided that the Armenian soldiers would evacuate Agdam on November 20, 2020, Kelbajar on November 25, 2020 (this date was determined as November 15, 2020 before additional time was given) and Lachin on December 1, 2020.

According to politologist Sergey Markov, "The most important expectation created when the Russian Peace Force came to the region right after Armenia signed the surrender treaty was "to preserve peace in the region". Subsequently, serious agreements will be under way for the re-annexation of Karabakh to Azerbaijan. In the upcoming period, Armenians who will stay in the region will be integrated into Azerbaijan". The politologist also said, "such a treaty would contribute to the development of friendly relations, not war, in the region". ${ }^{101}$ 
According to Sergey Markedonov's notes once again: "They ask in Yerevan: Why didn't Russia intervene and defend Armenia before?", What kind of intervention are we talking about? Russia did not want to perform military intervention. And what's more, it didn't need it. At this point, it is necessary to understand the asymmetry between Moscow and Yerevan. For Armenia, Karabakh and its environs are a single security complex, this is not only a military-political but also a psychological and emotional identity problem. The Karabakh myth replaced a human complex victim of "genocide" in the Armenian narrative after the collapse of the USSR.

For Russia, Armenia is different, Karabakh is different, and other incidents around are completely different. Moscow's stance on this issue has always been consistent: "It must be given to Baku!"

If there had been any military attempts against Armenia, military support would have been provided to Armenia by Russia. However, this was a risky situation because in that case, Turkey would have also provided support. The support that Armenia expected and that Moscow would have provided were not the same". ${ }^{102}$

Russia's "non-intervention" and "inaction" in the September 27 war also led to a number of speculative comments by political strategists and journalists: It was alleged that the Kremlin desired to punish Pashinyan and teach him a lesson, make him resign, or at least close the offices of American NGOs. After the war, Pashinyan acknowledged that these rumours had reached him and also implied that he had asked Putin about them directly from the parliamentary rostrum.

Armenian politologist Ruben Megrabyan, on the other hand, said, "The defeat of Armenia means the defeat of the West, too". ${ }^{103}$

Azerbaijan declared November 8, 2020 as the Victory Day after the war ${ }^{104}$ and a Victory Parade was held in Baku on December 10, 2020. President of the Turkish Republic Recep Tayyip Erdoğan also attended this parade, during which Azerbaijani and Turkish flags fluttered together.

Immediately after the Victory Parade in Azerbaijan, Russian historian and politologist Andrey Zubov published an article titled "Putin's Total Defeat". In his article, he stated: "When a peace agreement was signed in the Caucasus about a month ago, a dispute was raised about whether Turkey would be the guarantor of the peace on par with Russia, Russia said "no", but Turkey said "yes". The last month proved Putin wrong and Erdoğan right, and Turkey became the guarantor of the situation in South Caucasus. Now, other questions come to mind, "is it the guarantor of peace?". I take a dim view of the fears of Armenians who are afraid that Turkey and Azerbaijan would enter Yerevan and annihilate Armenia in 48 hours. Neither Azerbaijan nor Turkey would take this path. This contradicts with their international interests, and Turkey is a NATO country.

In fact, the close combat of the war has been over. Of course, as long as those in Yerevan do not overthrow Pashinyan and then make a mistake and pursue a rematch. This

102 Дмитриев а 2020

103 Дмитриев b 2020

${ }^{104}$ This date had been planned to be November 10. However, since it was the death anniversary of Atatürk, this date was pushed to November 8 , the day of liberation of Shusha. 


\title{
Vefa KURBAN - Oğuzhan ERGÜN
}

would be a disaster for Armenia, and the Armenians have realized that no one will fight for them anymore: Neither Russia nor France nor Trump nor Biden. However, Turkey would fight for Azerbaijan...".

In what follows, Zubov added: "Russia lost Azerbaijan. This two-century-long process came to an end, which included Valerian Zubov's Caspian campaign, General Paskevich's annexation activities, and the Bolsheviks' entry into the region in April 1920. Azerbaijan is now neither a part nor a satellite of Russia anymore...

Putin has lost this game of chess". ${ }^{105}$

However, there is now an important issue to be considered. In contrast to what Rockefeller mentioned in his letter to President Eisenhower in 1956, Turkey is not "fish on the hook". ${ }^{106}$ Turkey is a great power in the region, an important actor, and Russia is aware of this situation.

On December 8, 2020, protests were held in Armenia, opposition parties formed "National Liberation Committees" and these committees demanded Pashinyan's resignation. According to Russian politologist Irina Busygina, after the NagornoKarabakh war, Pashinyan lost his subjectivity under the influence of major foreign actors, and Busygina even argued that the situation in the region was shaped by foreign countries. ${ }^{107}$

Statements from Stratfor Organization, whose comments we also refer to above, held that it was not yet possible to expect permanent peace in the region, and emphasized the political crisis in Armenia and pointed out that the calls for the resignation of the government in Armenia became intensified, and this situation would make the ethnic conflicts in the region reach different dimensions in the future. ${ }^{108}$

\section{Discussion and Conclusion}

Russia has a state mentality that has matured the architectural conditions determined by the strategic culture from the Grand Duchy of Moscow to the Federation of today and has carried out its moves with sustainability. Although the geopolitical shaping spread over a long period of time, it continued to reach its national goals after gathering the necessary power thanks to its continental state reflex. The historical process reflects on the positioning ${ }^{109}$ of the subject (Enemy-Friend-Rival) in the social theory of international politics through collective memory. Russian administrations have never developed friendship norms, and never escalated the Turkish entity beyond rival in the spectrum of enemy-rival and friend since prior to the Turkish Republic. Although their political approaches reflect ad hoc alliances in the global arena according to the requirements of the situation, it is reflected in the events that Russia is in the position of an enemy that has to be kept in mind in the region and, albeit culturally, against the territories of rivals. The sale of long-range high-altitude air defence missile systems ( $\mathrm{S}$

\author{
105 Зубов 2020 \\ 106 Değer 2018, s. 18 \\ ${ }^{107}$ Бусыгина 2020 \\ 108 Stratfor 2020 \\ ${ }^{109}$ Wendt 2016, s. 318
}


400), which created an impact in the global strategic area, the tension it created in Syria and finally its attitude towards the Turkish military presence after the Nagorno-Karabakh war reflected this trilogy again. According to Wendt, friendship is a role structure in which two simple independent rules must be followed: "1. Disputes will be resolved without fighting or without threat of war (the rule of non-violence) 2 . If a third party threatens the security of a member, they will fight as a team (the rule of mutual aid). Friendship is only about security and does not have to have anything to do other issues ${ }^{110}$.

Russia's active interventions in Crimea and Eastern Ukraine in 2014 led to the implementation of "difficult policies" against Russia. The EU countries, G-7 countries (the UK, Germany, Italy, Canada, the USA, France and Japan) and other countriesimposed sanctions. The NATO Secretary General of the period stated that all organizations ended their cooperation with the Russian Federation. Although it is stated that the economic and financial sanctions coupled with the decrease in oil prices as of 2014 have made the country go through difficult times, it is quite difficult to argue that they have created a noticeable change in the foreign policy. It is observed in the statistics of goods and oil production and exports that there was a considerable decline in economic data in 2016, but there has been a relatively upward trend since 2018. It seems that such sanctions do not have the authority to prevent Russia from illegal activities.

Figure 9: Produçtion of Crude Oil.

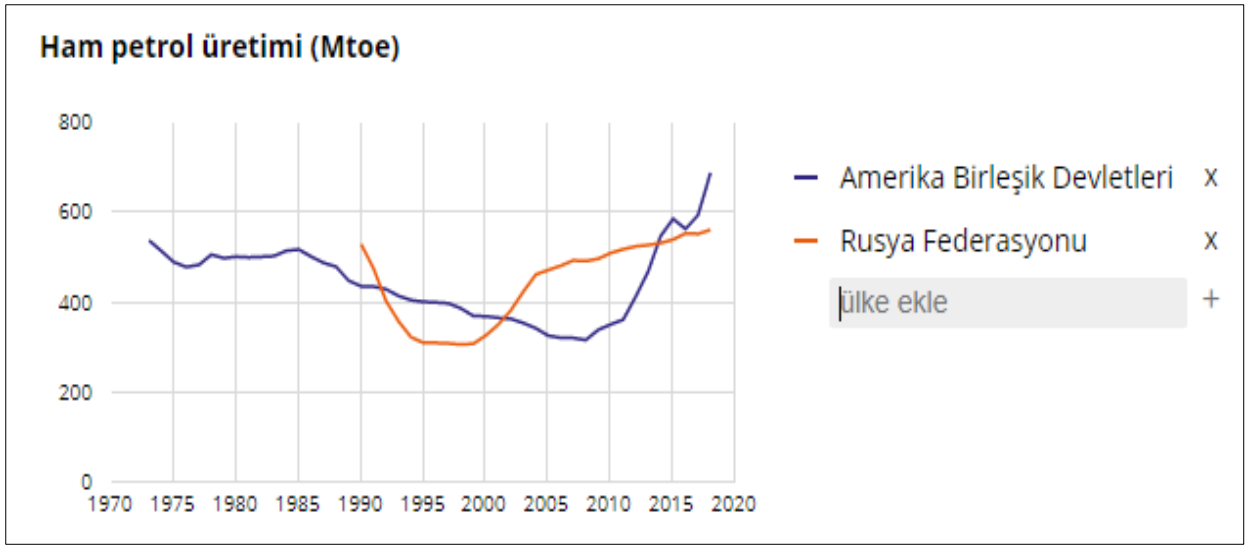

Source: https://www.iea.org/data-and-statistics/datatables/?country $=$ WORLD\&energy $=$ Oil 


\section{Vefa KURBAN - Oğuzhan ERGÜN}

Figure 10: (Source https://data.wto.org).

\begin{tabular}{|c|c|c|c|c|c|c|c|c|}
\hline Indicator & $\begin{array}{l}\text { Merchandise exports } \\
\text { by product group - } \\
\text { annual (Million US } \\
\text { dollar) } \\
\end{array}$ & & & & & & & \\
\hline $\begin{array}{l}\text { Reporting } \\
\text { Economy }\end{array}$ & Product/Sector & 2013 & 2014 & 2015 & 2016 & 2017 & 2018 & 2019 \\
\hline $\begin{array}{l}\text { Russian } \\
\text { Federation }\end{array}$ & $\begin{array}{l}\text { SI3_AGG - TO - } \\
\text { Total merchandise }\end{array}$ & 521836 & 496807 & 341419 & 281710 & 352943 & 443914 & 419850 \\
\hline $\begin{array}{l}\text { Russian } \\
\text { Federation }\end{array}$ & $\begin{array}{l}\text { SI3_AGG - AG - } \\
\text { Agricultural } \\
\text { products }\end{array}$ & 25574 & 27898 & 23429 & 24709 & 30065 & 34664 & 33722 \\
\hline $\begin{array}{l}\text { Russian } \\
\text { Federation }\end{array}$ & $\begin{array}{l}\text { SI3_AGG - AGFO - } \\
\text { Food }\end{array}$ & 16045 & 18793 & 15996 & 17129 & 20884 & 24648 & 24567 \\
\hline $\begin{array}{l}\text { Russian } \\
\text { Federation }\end{array}$ & $\begin{array}{l}\text { SI3_AGG - MI - } \\
\text { Fuels and mining } \\
\text { products }\end{array}$ & 396161 & 369131 & 236396 & 163989 & 209142 & 263390 & 248032 \\
\hline $\begin{array}{l}\text { Russian } \\
\text { Federation }\end{array}$ & $\begin{array}{l}\text { SI3_AGG - MIFU - } \\
\text { Fuels }\end{array}$ & 372036 & 346119 & 216101 & 145734 & 186285 & 237851 & 221689 \\
\hline $\begin{array}{l}\text { Russian } \\
\text { Federation }\end{array}$ & $\begin{array}{l}\text { SI3_AGG - MA - } \\
\text { Manufactures }\end{array}$ & 86511 & 85830 & 70262 & 69203 & 84185 & 88912 & 83455 \\
\hline $\begin{array}{l}\text { Russian } \\
\text { Federation } \\
\end{array}$ & $\begin{array}{l}\text { SI3_AGG - MAIS - } \\
\text { Iron and steel }\end{array}$ & 21017 & 20906 & 15166 & 14201 & 19757 & 24584 & 19351 \\
\hline $\begin{array}{l}\text { Russian } \\
\text { Federation } \\
\end{array}$ & $\begin{array}{l}\text { SI3_AGG - MACH - } \\
\text { Chemicals }\end{array}$ & 23533 & 23517 & 19950 & 17655 & 20936 & 22044 & 21721 \\
\hline $\begin{array}{l}\text { Russian } \\
\text { Federation }\end{array}$ & $\begin{array}{l}\text { SI3_AGG - } \\
\text { MACHPH - } \\
\text { Pharmaceuticals }\end{array}$ & 592 & 623 & 549 & 646 & 742 & 800 & 856 \\
\hline $\begin{array}{l}\text { Russian } \\
\text { Federation }\end{array}$ & $\begin{array}{l}\text { SI3_AGG - MAMT } \\
\text { - Machinery and } \\
\text { transport equipment }\end{array}$ & 21365 & 20107 & 18509 & 18754 & 22471 & 20642 & 21593 \\
\hline $\begin{array}{l}\text { Russian } \\
\text { Federation }\end{array}$ & $\begin{array}{l}\text { SI3_AGG - } \\
\text { MAMTOF - Office } \\
\text { and telecom } \\
\text { equipment }\end{array}$ & 2457 & 4025 & 2938 & 2435 & 2508 & 2181 & 3080 \\
\hline $\begin{array}{l}\text { Russian } \\
\text { Federation }\end{array}$ & $\begin{array}{l}\text { SI3_AGG - } \\
\text { MAMTOTEP - } \\
\text { Electronic data } \\
\text { processing and } \\
\text { office equipment } \\
\end{array}$ & 437 & 1843 & 1638 & 294 & 955 & 647 & 801 \\
\hline $\begin{array}{l}\text { Russian } \\
\text { Federation }\end{array}$ & $\begin{array}{l}\text { SI3_AGG - } \\
\text { MAMTOTTL - } \\
\text { Telecommunications } \\
\text { equipment }\end{array}$ & 1825 & 1806 & 1096 & 1939 & 1320 & 1304 & 2053 \\
\hline $\begin{array}{l}\text { Russian } \\
\text { Federation }\end{array}$ & $\begin{array}{l}\text { SI3_AGG - } \\
\text { MAMTOTIC - } \\
\text { Integrated circuits } \\
\text { and electronic } \\
\text { components }\end{array}$ & 195 & 376 & 204 & 202 & 233 & 230 & 226 \\
\hline $\begin{array}{l}\text { Russian } \\
\text { Federation }\end{array}$ & $\begin{array}{l}\text { SI3_AGG - } \\
\text { MAMTTE - } \\
\text { Transport equipment }\end{array}$ & 8071 & 6414 & 6696 & 6386 & 7967 & 7191 & 7585 \\
\hline $\begin{array}{l}\text { Russian } \\
\text { Federation }\end{array}$ & $\begin{array}{l}\text { SI3_AGG - } \\
\text { MAMTAU - } \\
\text { Automotive products }\end{array}$ & 3773 & 3423 & 2769 & 2784 & 3809 & 3327 & 3760 \\
\hline $\begin{array}{l}\text { Russian } \\
\text { Federation } \\
\end{array}$ & $\begin{array}{l}\text { SI3_AGG - MATE - } \\
\text { Textiles }\end{array}$ & 453 & 470 & 387 & 426 & 499 & 552 & 601 \\
\hline $\begin{array}{l}\text { Russian } \\
\text { Federation }\end{array}$ & $\begin{array}{l}\text { SI3_AGG - MACL - } \\
\text { Clothing }\end{array}$ & 337 & 406 & 321 & 346 & 437 & 413 & 510 \\
\hline
\end{tabular}




\section{The War Between Period and Exclamation Mark}

Formative political strategic moves are generally built upon two practices, i.e. deterrence and coercion, and two attitudes, i.e. direct and indirect. Russia has shown the success of implementing these four dynamics synchronously with appropriate timing and has been the side with most wins. Due to its current situation, the Karabakh Case has been closed for a certain period of time under the conditions determined by Russia.

Although Armenia could not directly fulfil its mission as a society that is closed to all kinds of dialogue and criticism regarding the Turkish existence, it caused the establishment and strengthening of the Russian presence in the Karabakh geography. In the upcoming period, although it loses its conventional military influence power in this region, it will continue the Nagorno-Karabakh conflict on an ethno-political ground under Russia's protection and political influence. The potential for asymmetric military and terrorist actions should not be overlooked. The Armenian Conflict was affirmed by the discourse and physical support that encouraged unresponsiveness and even Armenian aggression during and before the war in which it was an effective social manipulation apparatus used by Western states against the Turkic World.

Azerbaijan won a military victory over Armenia thanks to its relatively superior material and moral power. Azerbaijan demonstrated that it established a "national" army that is independent from Russian influence, well-trained, disciplined, well-equipped and capable of achieving strategic results. The military victory has not yet brought along a complete political victory. The land annexations that were determined as the complete success criterion by the Azerbaijani political authority and the complete cleansing of the Armenian occupation elements (civil and military) from the territories have not been completely realized. On the contrary, a significant number of withdrawn elements seem to have been brought back to the lands on target. The return of the Armenian fugitives who Russia protected by creating a buffer zone is likely to become the focus of new problems through prospective patronage policies. The protection resulting from the granting of Russian citizenship may conceal armed conflicts and acts of terrorism. If the agreement phase could start, the issue of Russian citizenship should be scrutinized. Another threat that needs to be scrutinized is Russian journalist Maksim Shevchenko's statement in a radio broadcast on December 28, 2020 that 10.000 Russian soldiers were deployed in Karabakh ${ }^{111}$. Russia's long-term plans related to this field must be analysed without being in the shadow of the populist discourse of victory. On the other hand, as stated by Russian Foreign Minister Lavrov, Turkish troops ${ }^{112}$ had not been deployed in Nagorno-Karabakh. The Observation Center, which has come into operation, serves as an observer and is protected by the Azerbaijan Army. A conventional Turkish military unit with fighting force and in the form of peacekeeping force has not entered the region.

Considering the outcome of the war within the framework of game theory, Armenia experienced the least loss in the loss-damage spectrum thanks to the buffer zone Russia established and its proposals, and accepted the map of "Final situation" and its terms, thus it agreed the biggest yield (maximin) in the spectrum. The loss section of the spectrum could be thought as resetting the war from the occupied lands and carrying it to

${ }^{111}$ Kemaloğlu 2021

${ }^{112}$ Lavrov 2021 


\section{Vefa KURBAN - Oğuzhan ERGÜN}

their own lands, economic and demographic crisis, etc. It can be thought that Azerbaijan made a compromise by accepting the lower cost outcomes (minimax) in the victory spectrum that it can achieve by taking into account the ballistic missile threat ${ }^{113}$, especially the Iskander missiles, which concentrate on the civilian population, Baku and its industrial facilities. Zero-sum games cannot be played in real life.

Turkey produced a direct and indirect effect as a deterrent force against the third parties of the victory. However, the status of the influence in the ongoing and subsequently developing political process has not been clarified yet. This process made a major contribution to the strengthening of a collective identity among the peoples of Turkey and Azerbaijan. It is thought to contribute to the formation of a soft power that will have an impact on the Turkestan cultural basin. "Strategic communication" ways must be prepared and opened to affect the federation administrations of the hostile peoples of Turkish origin and Muslims.

Being one of the biggest losses of Turkey in this era, the loss of land contact with Turkestan will be reversed when the "Nakhchivan Corridor"114 becomes functional, which is a geostrategic success. However, the realization of the geopolitical connection under the control of Russia is not a geostrategic success, but a strategic success in economic and other fields. Having been disconnected in 1921, the Western axis of Nakhchivan-Turkey ought to be re-established under the control of Azerbaijan. It is stated that even the rumours regarding the corridor cause anxiety in $\operatorname{Iran}^{115}$. The state of being stuck between the Ottoman-Uzbek Khanate-Mughal states, which took place in the strategic culture of Iranian governments within the framework of historical security dilemmas, also manifests itself in the current geography. This supports "Armenian Dagger" ${ }^{116}$, which divides Turkey and the Turkic World.

The cemre having fallen on the frozen problem and lands will continue to heat this area. The countries placed in the position of target-rival-enemy such as Turkey and Azerbaijan should anticipate the end state that the geopolitical scenario desires to achieve. They need to strengthen their local and regional "sociological topographies", and in this context, develop their asymmetrical combat and/or intervention capabilities. Following its five-year-long role as the Peacekeeping Force for five years, Russia's granting Russian citizenship to the Armenians of Karabakh and providing permanent settlement in the region would constitute the worst scenario, and appropriate measures should be considered ahead of time.

The role of information warfare in the global strategic competition has become more evident in recent years. The emergence of the Internet, the increase of social media's impact on opinions, and the public's direct access to more information than ever before have fundamentally changed the information ecosystem. However, it becomes almost impossible to distinguish correct information from poor quality or incorrect content. This

\footnotetext{
113 Yeni Çă̆ 2021

${ }^{114}$ Aliyev 2021

${ }^{115}$ BBC 2021

${ }^{116}$ Gadjiev 2021
} 
means that false or intentionally misleading information with an economic or political purpose spreads much faster than other methods and means.

The international public support for Azerbaijan and Turkey was very limited and weak throughout the war. Therefore, activities that are called "hostile social manipulation" and will harm the target state, such as targeted/deliberate social media campaigns, sophisticated fraud, cyber bullying and harassment, the dissemination of rumours and conspiracy theories, and the use of other means and approaches, require a different strategic attitude and architecture. This situation has led to the emergence of "Multi-Domain Operations (MDB)" concepts in the literature on political war.

Hostile social manipulation efforts, which are frequent in wartime, will have an impact on a society to the extent that security gaps allow. After the war, manipulations, especially those on social media, are increasingly spreading, and statements and fictional images that causes confusion among Azerbaijani and Turkish people are being published. In the fight against misinformation, disinformation, fake news, propaganda and others, gaining more awareness or having people gain more awareness about the media ecosystem has turned from the risk area to the threat area. In order to crown military victory with political and cyber victory, there is a lot of work area that requires being organized, but there is limited time. Cemre continues to warm these lands. The absence of False Spring requires "unity in language, opinion and work". 


\section{Vefa KURBAN - Oğuzhan ERGÜN}

\section{BIBLIOGRAPHY}

\section{a. Books}

Barbero 1993

Brzezinski 2005

Danilov 1996

Değer 2018

Ergün 2020

Ferro 2002

Fuller 2010

Gafarli et.al 2020

Hard and Negri 2000

Hayit 1995

Kagan 2006

Kiernan 2003

Kissinger 2016
J. Martin Barbero, Communication, Culture and Hegemony, From the Media to Mediations, Çev.: E. Fox ve R. E. White, London, Sage.

Zbigniew Brzezinski. Büyük Satranç Tahtası: Amerika'nın Küresel Üstünlüğ̈̈ ve Bunun Jeostratejik Gereklilikleri, Ankara, İnkilap Yayınları.

Dimitri Danilov, Russia's Search for an International Mandate in Transcaucasus, Bruno Coppiers (der.), Contested Borders in the Caucasus, Brüksel: Vubpress.

M. Emin Değer, Emperyalizmin Tuzağındaki Ülke Oltadaki Balık Türkiye, Kilit yayınları, Ankara.

Oğuzhan Ergün, "Siyasi Çatışmadan, Silahlı Siyaset ve Sanal Sosyal Savaşa Postmodern Güç Siyaseti”, Sosyal Bilimler Alanında Akademik Çalışmalar, Ed. Prof. Dr. Hasan Babacan, Gece Kitaplığı, Ankara.

Oğuzhan Ergün ve Vefa Kurban, Jeopolitik Şekillendirme ve Türk Rus ilişkileri, Postmodern Jeopolitik, Infosfer Kirliliği ve Güç Siyaseti, İstanbul, Yeditepe.

Marc Ferro, Fetihlerden Bağımsızlık Hareketlerine Sömürgecilik Tarihi, 13. Yüzyıl-20. Yüzyıl Çev. M. Cedden, Ankara, İmge.

Graham E. Fuller, İslamsız Dünya, Çev.: H. Kaya, İstanbul, Profil.

O. Gafarli, A. Anapiosyan, M. Fatih, K. Chapichadze, "The Role Of Global And Reglonal Actors In The South Caucasus", Caucasus Edition - Journal of Conflict Transformation", http:/caucasusedition.net/old/wp-content/uploads/2016/06/ Actors.pdf, (Erişim Tarihi:19.12.2020).

Michael Hard and A. Negri, Imparatorluk, Bas. Çev. A. Yılmaz, İstanbul.

Baymirza Hayit, Türkistan Devletlerinin Millî Mücadeleleri Tarihi, Türk Tarih Kurumu Yay. Ankara.

Robert Kagan, Dangerous Nation, America's Foreign Policy from Its Earliest Days to the Dawn of the Twentieth Century Reprint Edition, New York: Vintage.

Victor G. Kiernan, Colonialism" ed. W. Outhwaite, in The Balckwell Dictionary of Modern Social Thought, New Jersey, Blackwell.

Henry Kissinger, Dünya Düzeni, Çev. S. Gül, İstanbul, Boyner. 
Kurban et.al 2020

Mann 2017

Potto 1995

Robinson et.al 2018

Rubinstein 1976

Suny 2006

Şimşir 2011

Tikhomirov 1897

Wendt 2016

Üzgel 2001

Yildirim 2018

Zhukovskiǐ 1915

Киняпина et.al 1984

Потто 1887

Харюков 1995
Vefa Kurban, Hazar Ibrahim, G. Saynur Derman, A.Nafiz Ünalmiş, Araz Aslanli, Burcu Gül, Nur Çümen, Güney Kafkasya'nın Parlayan Yıldızı Azerbaycan, Tarihi, Siyasi Yapisl, Enerji boyutu ve Jeopolitik Konumu ile, Nobel Yayıncilık, Ankara.

Michael Mann, Iktidarın Tarihi, Küresel Imparatorluklar ve Devrim, 1890-1945 Cilt III. Çev. A.R.Gürgen v e Ö. Balkılıç. Ankara, Phoenix.

Vasiliy Aleksandroviç Potto. Kavkazskaya Voyna, Tom: I-V, Moskva 2006-2007 Cilt 1, Satvropol: Kavkazskiy Kray.

Linda Robinson, Todd C. Helmus, Raphael S. Cohen, Alireza Nader, Andrew Radin, Madeline Magnuson, Katya Migacheva, Modern Political Warfare Current Practices and Possible Responses, Rand Corporation, https:/www.rand.org/pubs/ research_reports/ RR1772.html Erişim Tarihi 07.04.2018

Alvin Rubinstein, "The Transformation of Russian Foreign Policy", Karen Dawisha (der.), The International Dimension of Post-Communist Transition in Russia and the New States of Eurasia, New York: M.E. Sharpe.

Ronald Grigor Suny (Ed), Russia, The Twentieth Century, Cambridge University Press.

Bilal N. Şimşir, Azerbaycan, Azerbaycan'ın Yeniden Doğuş Sürecinde Türkiye-Azerbaycan İlişkileri, Ankara.

K.İ. Tikhomirov, Turkestan, izdanie, Moskva.

Alexander Wendt, Uluslararası Siyasetin Sosyal Teorisi 2. Bas. Çev. H. S. Ertem ve S. G. Öner. İstanbul, Küre.

İlhan Üzgel, "1980-1990 ABD'yle İlişkiler", Türk Dış Politikası Kurtuluş Savasından Günümüze Olgular, Belgeler, Yorumlar, Baskın Oran (der.), Cilt II, İstanbul, İletişim.

İbrahim Yildirim, Azerbaycan-Ermeni İlişkileri ve Dağlık Karabağ Sorunu. İstanbul: Babıali Kültür Yayınları.

Valentin Alekseevich Zhukovskiū, Snoşenie Rossii s Buharoy $i$ Hivoy za poslednie trehsotletie, Petrograd.

КИНЯПИНА Н.С., БЛИЕВ М.М., ДЕГОЕВ В.В., Кавказ $и$ Средняя Азия во внешней политике России: вторая половина XVIII - 80-е годы XIX в., Москва: Изд-во Московского университета.

Василий Александрович Потто, Кавказская война в отдельных очерках, эпизодах, легендах и биографиях, Всего томов 5, том1, Издание Книжнего Склада В.А.Березовскаго, С. Петербург.

Л. Н. Харюков, Англо-русское соперничество в Центральной Азии и Исмаилизм, Издательство МГУ. 


\section{Vefa KURBAN - Ŏguzhan ERGÜN}

\section{b. Articles}

Aslanl 2020

Çapraz 2011

Friedman 2020b

Friedman 2020a

Gadjiev 2021

Gaffarli 2011

Gönder 2016

Halbach 2016

Liangxiang 2005

Lin 2020 a

Lin 2020 b

Tuncel 2016

Yaşin 2021
Araz Aslanlı, https://www.aa.com.tr/tr/analiz/-agit-minsk-grubunasil-olustu-ne-ise-yaradi/2008339, (Erişim Tarihi: 11.12.2020).

Hayri Çapraz, “Çarlık Rusyası'nın Türkistan'da Hâkimiyet Kurması" SDÜ Fen Edebiyat Fakültesi Sosyal Bilimler Dergisi, Aralık 2011, Say1:24, pp.51-78.

George Friedman, https://www.businessinsider.com/ stratforfounder-george-friedman-be-ready-for-war-2016-3, (E. T.: 21.12.2020).

George Friedman, https://geopoliticalfutures.com/armeniaazerbaijan-and-a-dangerous-conflict/, (E.T. 18.12.2020).

Amur Gadjiev, Güney Kafkasya'da kara güzergahlarının yeniden açılması: Sorunlar ve beklentiler", https://tr.sputniknews.com/columnists/202101271043675483guney-kafkasyada-kara-guzergahlarinin-yeniden-acilmasisorunlar-ve-beklentiler/ Sputnik News, Erişim Tarihi 20.01.2021. Orhan Gaffarli, “ABD-Rusya İlişkilerinde Yenilenme Süreci ve Kafkasya Faktörü”, Bilge Adamlar Stratejik Araştırmalar Merkezi, 08 Ağustos 2011, file:///F:/Transkafkasya/ABDlibre.pdf (Erişim tarihi 17.04.2016).

Çağatay Gönder, “Kaşgar Emirliği’nin Osmanlı Devleti’ne Tâbiiyeti”, Yakın Dönem Türkiye Araştırmaları 2, Vol:15, No.: 30, pp. 1-30.

Uwe Halbach "Religion und Nation, Kirche und Staat im Südkaukasus", SWP-Studie Stiftung Wissenschaft und Politik Deutsches Institut für Internationale Politik und Sicherheit, Berlin.

Jin Liangxiang, "Energy First: China and the Middle East", Shanghai Institute for International Studies, Middle East Quarterly, pp. 3-10. http://www.meforum.org/694/energy-first Christina Lin, "Syria in China's New Silk Road Strategy" Publication: China Brief Volume: 10 Issue :8 http://www.jamestown.org/programs/chinabrief/single/?tx ttne $\mathrm{ws}\left[\mathrm{tt} \_\right.$news] $=36264 \& \mathrm{cHash}=-$ ac6dfc2626 E. T. 12.12.2020.

Christina Lin, http://www.jamestown.org/programs/chinabrief/ single/?tx_ttnews[tt_news] $=36264 \&$ cHash $=$-ac6dfc 2626 Erişim Tarihi 12.12.2020.

Turgut Kerem Tuncel, "Karabağ’da Yaşanan “4 Gün Savaşı”nın Kisa Bir Değerlendirmesi” Yorum No: 2114.04.2016, HTTPS://AVIM.ORG.TR/TR/YAZAR/TURGUT-KEREMTUNCEL, (Erişim Tarihi:07.12.2020).

Gözde K. Yaşin, “Balkanlarda Pandora’nın Kutusu” 21. Yüzyıl Türkiye Enstitüsü, 23 Ocak 2021, https://21yyte.org/tr/ 
merkezler/bolgesel-arastirma-merkezleri/balkanlar-ve-kibrisarastirmalari-merkezi/balkanlarda-pandora-nin-kutusu Erişim Tarihi 15.01.2021

\section{d. Internet Sources}

Aliyev 2021

Aslanli 2020

Blair 2020

Cemre 2020

Erol 2018

Friedman 2020

Friedman 2020

Geldi 2020
ALIYEV: Azerbaycan'ı Nahçıvan ve Türkiye'ye bağlayacak demiryolu inşasına başlanıyor- BBC News Türkçe, 31 Aralık 2020, TRT Haber Nahçıvan ile Azerbaycan kara ve demiryoluyla birleşecek- Son Dakika Haberleri (trthaber.com) 4 Kasım 2020, Erișim Tarihi 15.01.2021

Araz Aslanlı, "AGİT Minsk Grubu nasıl oluştu, ne işe yaradı?”, https://www.aa.com.tr/tr/analiz/-agit-minsk-grubu-nasil-olustune-ise-yaradi/2008339, (Erişim Tarihi: 11.12.2020).

Avsat and Ahmet 2020 Şarkul Avsat - Şerif Egemen Ahmet, (17.10.2020) "Karabağ Savaşı İran'1 Bölüyor” https://turkish.aawsat.com/home/article/ 2569381/\%C5\%9Ferif-egemen-ahmet/karaba\%C4\%9Fsava $\% \mathrm{C} 5 \% 9 \mathrm{~F} \% \mathrm{C} 4 \% \mathrm{~B} 1-\mathrm{i} \% \mathrm{CC} \% 87 \mathrm{ran} \% \mathrm{E} 2 \% 80 \% 99 \% \mathrm{C} 4 \% \mathrm{~B} 1-$ b\%C3\%B61\%C3\%BCyor Erişim Tarihi: 01.12.2020)

Betty Blair, "Forging a Lasting Peace The Nagorno-Karabakh Conflict An Interview with John J. Maresca Former US Ambassador to the OSCE", https://www.azer.com/aiweb/ categories/magazine/41 folder/41 articles/41 maresca.html, (Erişim Tarihi:12.12.2020).

https://haber.sakarya.edu.tr/ilk-cemre-dustu-peki-cemredusmesi-ne-demek-h96191.html Erişim Tarihi 10.12.2020.

Seyfettin Erol, 05.03.2018, Putin'in Deklare Edilmemiş Stalin Pişmanlığı: Türkiye'yi Kaybetmek! Putin'in Deklare Edilmemiş Stalin Pişmanlığı: Türkiye'yi Kaybetmek! | ANKASAM Erişim Tarihi 10.01.2021. https://www.milligazete.com.tr/makale/ 1511330/prof-dr-m-seyfettin-erol/putinin-deklare-edilmemisstalin-pismanligi-turkiyeyi-kaybetmek (E. Tarihi: 12.12.2020)

George Friedman, "Armenia, Azerbaijan and a Dangerous Conflict", https://geopoliticalfutures.com/armenia-azerbaijanand-a-dangerous-conflict/, (Erişim Tarihi.18.12.2020).

George Friedman, "The Russo-Georgian War and the Balance of Power", https:/worldview.stratfor.com/article/russogeorgian-war-and-balance-power, (Erişim Tarihi:18.12.2020). Mahmut Geldi, Anadolu Ajansı, (09.10.2020) "Lübnanlı Şii Alim Tufeyli: Filistin'den Azerbaycan'a, Azınlıklar Bahanesiyle Müslümanlar Hedef Alınıyor" https://www.aa.com.tr/tr/dunya/lubnanli-sii-alim-tufeylifilistinden-azerbaycana-azinliklar-bahanesiyle-muslumanlarhedef-aliniyor/2001639 Erişim Tarihi 10.12.2020 


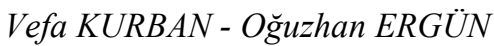

Gülbey 2021

Gülbey Gülbey, ASIMDER Başkanı: "Karabağ Ermenileri Rusya vatandaşı oluyor", Habertürk, https:/www.haberturk.com/igdir-haberleri/83468500-asimderbaskani-gulbey-karabag-ermenileri-rusya-vatandasi-oluyor (Erişim Tarihi:28.12.2020).

Hekimov 2020 Ruslan Hekimov, Azerbaycan Cumhurbaşkanı Aliyev: "Düşmanı Topraklarımızdan Kovduk ve Yeni Bir Gerçeklik Yarattı" Hürriyet Gazetesi, (09.12.2020) "İran'dan Azerbaycan'a: Desteğe Hazırız" https://www.hurriyet.com.tr/dunya/irandan-azerbaycanadestege-haziriz-41684407

https://politexpert.net/222574-politolog-sravnil-vvod-mirotvorcev-v-karabahe-ipridnestrove", (Erişim Tarihi:13.12.2020).

Ibrahimov 2020 Aydın Ibrahimov, "Ermeni Xisleti", Xalq Qezeti, 11 Aralık, 2020, http://xalqqazeti.com/az/news/65880 (Erişim Tarihi: 12.12.2020).

Kemaloğlu $2021 \quad$ Muhammet Kemaloğlu, “Azerbaycan'da 10.000 Rus Askeri mi var? "21. Yüzyıl Türkiye Enstitüsü, 31 Aralık 2020, https://21yyte.org/tr/merkezler/bolgesel-arastirma-

merkezleri/guney-kafkasya-iran-pakistan-arastirmalarimerkezi/azerbaycan-da-10-000-rus-askeri-mi-var Erişim Tarihi 15.01.2021

Lavrov $2021 \quad$ Lavrov 2021 Rusya Dişişleri Bakanı Lavrov, Türk birliklerinin Dağlık Karabağ'da bulunmayacağını açıkladı, KHA, Kırım Haber Ajans1, https://qha.com.tr/haberler/rusya-disisleribakani-lavrov-turk-birliklerinin-daglik-karabag-da-

bulunmayacagini-acikladi /275726 / 12 Kasım 2020, (Erişim Tarihi 15.01.2021).

Saltan 2020 Murat Saltan, "Hüseyin Bağcı: Paşinyan'ın yalanlarına inanılmiyor", https:/www.ankaramasasi.com/ haber/232918/ huseyin-bagci-pasinyanin-yalanlarina-inanilmiyor, (Erişim Tarihi: 16.12.2020).

Sönmez 2010 A. Sait Sönmez, "Moskova'nın Kutuplaşma Çabaları: Putin Dönemi Rus Dış Politikası”" T.C. Türk İşbirliği ve Kalkınma İdaresi Başkanlığı, Avrasya Etüdleri 37/2010-1 (37-76), s. 8

Suyundikov 2020 Suinbay Suyundikov, ABD'nin Orta Asya Politikaları", https://21yyte.org/tr/merkezler/bolgesel-arastirmamerkezleri/orta-asya-arastirmalari-merkezi/abd-nin-orta-asyapolitikalari\# ftn18, (Erişim Tarihi:25.12.2020).

YENİ ÇAĞ 2021 YENİ ÇAĞ Azerbaycan Hava Kuvvetleri Karargâh Komutanı: "Dünkü balistik füze sistemi imha edilmeseydi, füze Bakü’ye ulaşabilirdi”, Yeniçağ Gazetesi, 14.10.2020 Azerbaycan Hava Kuvvetleri Karargâh Komutanı: "Dünkü balistik füze sistemi 
АТАНЕСЯН 2020

БАРАНЕЦ 2020

БУСЫГИНА 2020

ДМИТРИЕВ 2020 b

ЗУБОВ 2020

КОЛОСОВ 2020

ЛАВРОВ 2020 а

ЛАВРОВ 2020 b imha edilmeseydi, füze Bakü’ye ulaşabilirdi” - Yeni Çă̆ (yenicag.info) Erişim Tarihi 15.01.2021

АТАНЕСЯН Григор, “Когда все недовольны". Почему Никол Пашинян не стал "армянским Манделой", https://www.bbc.com/russian/features-55139899, (Erişim Tarihi:06.12.2020).

БАРАНЕЦ Виктор, “Эксперт о конфликте в Нагорном Карабахе: это братоубийство никто не остановит”, https://uz.sputniknews.ru/radio/20200928/15069546/Ekspert-okonflikte-v-Nagornom-Karabakhe-eto-bratoubiystvo-nikto-neostanovit.html, (Erişim Tarihi: 12.12.2020)

БУСЫГИНА Ирина, “Политолог о протестах в Армении: Пашиняна не простят", https://m.rosbalt.ru/piter/2020/12/08/1876994.html, (Erişim Tarihi:12.12.2020).

ДМИТРИЕВ 2020 а Сергей, "Политолог Сергей Маркедонов: У Москвы нет желания менять статус-кво в Нагорном Карабахе", https://www.rfi.fr/ru/кавказ/20201126-политолог-сергеймаркедонов-у-москвы-нет-желания-менять-статус-кво-внагорном-карабахе, (Erişim Tarihi:13.12.2020).

ДМИТРИЕВ Сергей, "Политолог Рубен Меграбян: «Поражение Армении - это и поражение Запада», https://www.rfi.fr/ru/кавказ/20201119-политологрубен-меграбян-поражение-армении-это-и-поражениезапада, (Erişim Tarihi:13.12.2020).

ЗУБОВ Андрей (Российский историк и политолог, доктор исторических наук), “Тотальный проигрыш Путина. О чем говорит военный парад в Баку”, https://nv.ua/opinion/azerbaydzhan-parad-pobedy-chto-rossiyaproigrala-turcii-poslednie-novosti-50129586.html, (Erişim Tarihi: 11.12.2020).

КОЛОСОВ Евгений, “Политолог сравнил ввод миротворцев в Карабахе и Приднестровье...”, https://politexpert.net/222574-politolog-sravnil-vvodmirotvorcev-v-karabahe-i-pridnestrove

“Сергей Викторович Лавров”, http://government.ru/gov/persons/15/bio/, Erişim Tarihi: 11.12.2020).

“Сергей Викторович Лавров”, https://tass.ru/info/1433323, (Erişim Tarihi:11.12.2020).

МАРКЕДОНОВ 2020 МАРКЕДОНОВ “Армения и Азербайджан к дипломатическому формату добавляют силовой Маркедонов", 
https://uz.sputniknews.ru/radio/20200928/15071500.html, (Erişim Tarihi: 12.12.2020)

МКРТЧЯН 2020 МКРТЧЯН Марианна "В Баку гневно отреагировали на визит Никола Пашиняна в Нагорный Kapaбax",https://arminfo.info/full_news.php?id=47571\&_cf chl_jschl_tk_=3fa21d152c5705b $\overline{5} 1071 \mathrm{cb} 1 \mathrm{c} 20582042 \mathrm{af} \overline{8} \overline{7} 6 \overline{2}$ $0-16072 \overline{69} \overline{65}-0-$

ATSANV0OmbCGDASZnAVo9evclSGfQpnG3aTmuZ0zf9BMqLpjVw-

9WXu6epMB2KfwsCPzKzsAnnldT0y7TdIFbidBS497u2ph07 asop8X2tDAiyv8oqVDLYt42JGa6pEjY_B9vSBO22fvyl0fh6f P6gPbadhd2UEn9nX0ir2GFtIVARlypJMMAKoJ4xjEl hRgi1 vsf5Redp0iEgqtnnZXq6KjlzVMjbm2k_A0CsJKAFR3pFTB1 Aqc7hHD0UQ110E_6kzUXKdAZTkwH8G59kWm2CShRMa BWkzHQ7NjBqMe6FsEGbHPJV7oX2HouX-zDk91pnUyjklHvibZ9pVu4lMJXA4CfpYOLVdJCgMcAdFvMcNIa0VH0G0BRbmeysjCilR5ofRy5_7I6XknOr_oQN Q, (Erişim Tarihi: 06.12.2020).

НАВАЛЬНЫЙ 2021 НАВАЛЬНЫЙ: «Я просто аплодирую Пашиняну»", https://rus.azatutyun.am/a/29968512.html, (Erişim Tarihi: 28.01.2021).

ПАШИНЯН 2020 а "ПАШИНЯН - о фразе "Арцах - это Армения и точка": почему Армения не может пойти на односторонние уступки", https://newsarmenia.am/news/nagorno_karabakh/pashinyan-ofraze-artsakh-eto-armeniya-i-tochka-pochemu-armeniya-nemozhet-poyti-na-odnostoronnie-us/, (Erişim Tarihi: 06.12.2020).

ПАШИНЯН 2020 b ПАШИНЯН: “Арцах - это Армения, и точка» - премьерминистр Армении", https://jam-news.net/ru/apцах-этоармения-и-все-премьер-ми/, (Erişim Tarihi: 06.12.2020).

ПАШИНЯН 2020 с "ПАШИНЯН принял участие в торжествах по случаю Дня Победы в Степанакерте", https://www.kavkazuzel.eu/articles/320258/, (Erişim Tarihi:06.12.2020).

ПАШИНЯН 2020 d ПАШИНЯН "Биография премьера Армении Никола Пашиняна", https://tass.ru/info/5184054, (Erişim Tarihi: 25.12.2020)

СЕДДОН 2020 СЕДДОН Макс, "Как Никол Пашинян пришел к власти в Армении", https://www.vedomosti.ru/politics/articles/2018/05/08/768957pashinyan-prishel-vlasti, (Erişim Tarihi; 06.12.2020).

ФЕЛЬГЕНГАУЭР 2020 ФЕЛЬГЕНГАУЭР Павел, “«Управление у армянской армии было как в эпоху Наполеона», “Военный эксперт 
Павел Фельгенгауэр оценил итоги Карабахской войны с точки зрения эффективности применявшегося в ней российского оружия.", https://m.rosbalt.ru/world/2020/11/26/1874884.html, (Erişim Tarihi:12.12.2020).

\section{e. Media News}

BBC 2021

BBC İzleme Servisi "Azerbaycan ve Nahçıvan arasındaki koridor Tahran'ı endişelendiriyor: Türk ülkeleri arasındaki ticarette kavşak olan İran bu özelliğini yitirebilir”, 29 Kasım 2020, Erişim tarihi 15.01.2021

ПОЛИТИКА 2019 ПОЛИТИКА 2019 “В Мюнхене началась встреча Никола Пашиняна и Ильхама Алиева", https://ru.armeniasputnik.am/politics/20200215/22070775/VMyunkhene-nachalas-vstrecha-Nikola-Pashinyana-i-IlkhamaAlieva.html, (Erişim Tarihi:06.12.2020).

HT 2020

"Çin'den 30 yılın en yüksek dış ticaret fazlası", Bloomberg HT (07.12.2020) https://www.bloomberght.com/cin-den-30-yilinen-yuksek-dis-ticaret-fazlasi-2270085, (Erişim Tarihi: 20.12.2020).

TÜRKIYYE ENSTİTÜSÜ 2020 “21. Yüzyıl Türkiye Enstitüsü Batı Bölge Teorisi (Çin’in Büyük Türkistan Politikası)", https://21yyte.org/tr/merkezler/bolgesel-arastirmamerkezleri/asya-pasifik-arastirmalari-merkezi/bati-bolgeteorisi-cin-in-buyuk-turkistan-politikasi

GORBY 2020 “Декабрь-91, 1 - 25 декабря. Развал CССР. Беловежские соглашения и отставка Президента СССР, https://www.gorby.ru/cccp/act/, (Erişim Tarihi:07.12.2020).

THE NEW YORK TIMMES 2020 "US Strategy Plan Calls For Insuring No RivalsDevelop", Patrick E. Tyler, New York Times, 8 Mart 1992.

WASINGTON POST 2020 "Keeping the US First, Pentagon Wouldpreclude a Rival Superpower" Barton Gellman, The Washington Post, 11 Mart 1992.

ИНОСМИ 2020 “Армяно-тбилисские корни Сергея Лаврова”, Georgian Times, Грузия, https://inosmi.ru/world/20080128/239202.html, (Erişim Tarihi: 11.12.2020).

YANDEX 2020 “«Скрытая» фамилия и национальность Сергея Лаврова”, https://zen.yandex.ru/media/id/5b72b81638af3e00aa0f757b/skr ytaia-familiia-i-nacionalnost-sergeia-lavrova5e2145a82fda8600b1cf7b77, (Erişim Tarihi: 11.12.2020).

ERMENISTAN KAMU RADYOSU 2020 "Lavrov'un planı ortaya çıkmış ve yırtılmıştır", https://tr.armradio.am/2020/09/04/lavrovun-planiortaya-cikmis-ve-yirtilmistir/, (Erişim Tarihi:11.12.2020). 


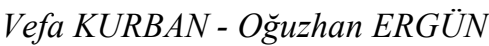

STRATFOR 2016

LENTA 2020

RBC 2020

DW 2020
"STRATFOR founder George Friedman: 'Be ready for war', https://www.businessinsider.com/stratfor-founder-georgefriedman-be-ready-for-war-2016-3, (Erişim Tarihi:21.12.2020). “«Признание Нагорного Карабаха — вопрос времени»”, https://lenta.ru/articles/2016/07/20/saakyan/, (Erişim Tarihi: 07.12.2020).

“Генсека ОДКБ обвинили в свержении конституционного строя B Армении", https://www.rbc.ru/politics/27/07/2018/5b5ae63f9a794702427f alab, (Erişim Tarihi: 06.12.2020).

“Бывший президент Армении Кочарян вновь арестован, https://www.dw.com/ru/бывший-президент-армениикочарян-вновь-арестован/а-49351417, (Erişim Tarihi: 06.12.2020).

KOMMERSANT 2020 “Обыски в РЖД были связаны с делом подрядчика”, https://www.kommersant.ru/doc/4465793, (Erişim Tarihi: 06.12.2020).

STRATFOR $2020 \quad$ "A Cease-Fire Will Only Freeze Azerbaijan and Armenia's Fight", https://worldview.stratfor.com/article/cease-fire-willonly-freeze-azerbaijan-and-armenia-s-fight, (Erişim Tarihi: 21.12.2020).

FINANCİAL TIMES 2020“Armenia's opposition leader named as prime minister”, https://www.ft.com/content/ffa885e6-52bd-11e8-b24ecad6aa67e23e, (Erişim Tarihi; 28.01.2021)

HÜRRIYET 2020 Hürriyet Gazetesi, (09.12.2020) “İran'dan Azerbaycan'a: Desteğe Hazırız" https://www.hurriyet.com.tr/dunya/irandanazerbaycana-destege-haziriz-41684407

NESA 2009 NESA/National Defense University,Washington, DC, April/Mai 2009 .

CRRC 2003 Caucasus Research Resource Center (CRRC), Religiosity in the South Caucasus,01.09.2013, s.3, Appendix A: International Religion Indexes

https://www.ncbi.nlm.nih.gov/pmc/articles/PMC4254791/table /T8/?report=objectonly

ARDA 2020

The Association of Religion Data Archives (ARDA) Din Veri Arşivleri Derneği Anketi, Soru: 164, 165, 172 https://www.thearda.com/Archive/Files/Codebooks/CAU12AR M_CB.asp (01.02.2021)

WORLD NUCLEAR ASSOCIATION 2021 “The Nuclear Fuel Report: Expanded Summary Global Scenarios for Demand and Supply Availability 2019-2040" s. 22, 40 https://worldnuclear.org/getmedia/b488c502-baf9-4142-8d12- 
42bab97593c3/nuclear-fuel-report-2019-expanded-summaryfinal.pdf.aspx. (Erişim Tarihi 10.01.2021)

ENERJİ PORTALİ 2019 Enerji Portalı, 28 EKİM 2019, “Türkmenistan Doğal Gaz Rezervi Bakımından 4. Sirada" | Enerji Portalı (enerjiportali.com). Erişim Tarihi 11.01.2021

T.C TİCARET BAKANLIĞI 2021a T.C Ticaret Bakanlığı“"Türkmenistan'ın Doğalgaz Üretim ve İhracat Potansiyeli” 07 Kasim 2019, https://ticaret.gov.tr/blog/ulkelerden-ticarihaberler/turkmenistan/turkmenistanin-dogalgaz-uretim-veihracat-potansiyeli Erişim Tarihi 10.01.2021

T.C TİCARET BAKANLIĞI 2021b

"Türkmen

Petrolünün Yeniden İhracatı İçin Yapılan Yarışı SOCAR Kazandı" 13 Ocak 2021, https://ticaret.gov.tr/blog/ulkelerdenticari-haberler/turkmenistan/turkmen-petrolunun-yenidenihracati-icin-yapilan-yarisi-socar-kazandi Erişim Tarihi 10.01.2021.

New Central Asia 2021 News Central Asia - nCa - Commissioning of the gascompressor station in the "Malay" gas field - the expansion of the export capacities of Turkmenistan's gas industry continues Friday, 15 January 2021 http://www.newscentralasia.net/ 2021/01/15/ commissioning-of-the-gas-compressor-station-inthe-malay-gas-field-the-expansion-of-the-export-capacities-ofturkmenistans-gas-industry-continues/Erişim Tarihi 10.01.2021

Government 2020 Лавров http://government.ru/gov/persons/15/bio/, (Erişim Tarihi:11.12.2020).

TASS 2020 Лавров, https://tass.ru/info/1433323 (Erişim Tarihi:17.12.2020) Armradio 2020 "Lavrov'un planı ortaya çıkmış ve yırtılmıştır", https://tr.armradio.am/2020/09/04/lavrovun-plani-ortayacikmis-ve-yirtilmistir/, (Erişim Tarihi:11.12.2020) 